\title{
Measuring the Effectiveness and Impact of COVID-19 Health Policies on Firms and UNSDGs: Evidence from China
}

\author{
Minhua Yang \\ Shanghai Maritime University, Shanghai, China \\ Vikash Ramiah \\ University of Wollongong in Dubai, Wollongong, Australia \\ Vijay Pereira \\ NEOMA Business School - Campus de Reims, Reims, France \\ Yama Temouri \\ Khalifa University, Abu Dhabi, United Arab Emirates and \\ Aston University, Birmingham, UK, and \\ Abhishek Behl \\ Jindal Global Business School, OP Jindal Global University, Sonipat, India
}

\begin{abstract}
Purpose: This paper documents and links firm and country-level outcomes to the United Nations Sustainable Development Goals (UNSDGs) by portraying how the Chinese economy has fared during the COVID-19 crisis. It does so by shedding light on the factors that determine the effectiveness of health policies implemented in China.

Design/Methodology/approach: Unlike prior literature, in which lagging performance measures are used, we use leading indicators to develop effectiveness score measures that enable us to calculate the percentage of firms in an industry that successfully responded to the health policies. The effectiveness scores are then used to dentify the determinants of efficiency, including financial variables, firm infection, geographical location of the spread, travel bans, lock down periods, and policies of home quarantine, health innovations and other innovative measures undertaken by the Chinese authorities.

Findings: Our detailed disaggregated results show many dimensions where abnormal returns are indeed associated with various health policies and that the effectiveness, influenced by firm size, profitability, firm infection and location. Our results remain robust when we control for various event windows and models and provides evidence of a strong UNSDG link, which we draw up a list for.
\end{abstract}

Research limitations/implications: Apart from our quantitative analysis approach, future studies can complement and add further insights by utilizing qualitative research approaches. 
Practical implications: Our results offer robust evidence for policy-makers and firm managers on how a crisis of such proportions and subsequent health policies is affecting different firms and why.

In addition, COVID-19 health policies open a new dimension to the work of Klemeš et al. (1997) in terms of energy demand reduction and lower emissions, factors linking to the UNSDGs.

Originality/value: Our study is the first to show detailed disaggregated results across many dimensions where abnormal returns are indeed associated with various health policies and that the effectiveness, influenced by firm size, profitability, firm infection and location.

Keywords: Pandemic, COVID-19, Chinese Stock Market, UNSDGs Effectiveness Scores 


\section{Introduction}

This paper explores the factors that contribute to the effectiveness of health policies in the containment of the coronavirus (COVID-19) in China, which is the research objective of this paper. In doing so, it documents and links outcome to the United Nations Development Goals (UNDGs), for example on health and wellbeing, education, poverty, hunger, water and sanitation, clean energy, peace and justice and environment- to name a few, which comes to our first research problem. We use a unique financial technique to measure the impact of the COVID-19 crisis on firms, which implicitly allows us to make inferences on how firms assist in curbing the spread of COVID-19, which is our second research issue. The third one is then to explore the factors of effectiveness.

In order to understand the multifaceted nature of managing and ultimately stopping the spread of COVID-19, we argue that it is crucial to consider financial aspects as policy-makers consult with the business community before finalizing any health measures. Thus, the effectiveness of such health policy implementation is yet to be analyzed to understand how organizations and markets reacted during the period of the current pandemic ${ }^{1}$. More specifically, organizations may implement health policies less effectively (or ineffectively) as they still have to maintain day-to-day operations to offer, for example customers' basic finance, utility services and limited transportation during the quarantine or lock-down period.

Unlike prior research that uses lagging indicators ${ }^{2}$ in investigating pandemics, we use financial data to develop effectiveness scores. This in turn allow us to identify which factors determine effectiveness in terms of finance fundamentals, the nature of firm infection, geographical location of the spread, travel bans, lock down periods, policies of home quarantine, health innovations and other innovative measures undertaken by the Chinese authorities. Although the health economics literature provides direct measures of health outcomes, such as recovery rates, these are lagging indicators, as opposed to leading indicators

\footnotetext{
${ }^{1}$ For the first research gap, although there are several theoretical evidence to show the relationship between the pandemic and its macroeconomic effects, the effects of health policy implementation are yet to be analysed to understand how organizations and markets reacted during the period ((Peckham, 2013; Keogh-Brown et al (2010). There are limited evidence on the relationship between the pandemic and UNSDGs. For the second gap, most of these related studies adopt the lagged indicators other than leading indicators, as there are few studies about the COVID-19 using leading indicators, such as stock prices (Alfaro et al. 2020; Ding et al, 2020).

${ }^{2}$ For the second gap, most of these related studies adopt the lagged indicators other than leading indicators, as there are few studies about the COVID-19 using leading indicators, such as stock prices (Alfaro et al. 2020; Ding et al, 2020).
} 
such as stock prices. Leading indicators provide policy-makers with feedback on what the market expects to happen if certain health policies are implemented. This crucially provides guidance for adjusting policies to achieve a higher level of effectiveness prior to the enforcement of regulation. Furthermore, the finance and economics literature fail to provide an explanation as to why the desired effects on stock returns are not achieved.

Given these gaps ${ }^{3}$ in the literature, this paper relates to a rapidly emerging literature, which studies the relationship between containment efforts of COVID-19 and the impact on listed firms. This paper contributes to the existing literature by investigating health policies implemented in China by utilising the insights from behavior finance theories to develop a measure of an effectiveness score in order to examine the effectiveness of these policies on listed firms. We also use the lens of media richness theory and contingency theory to explain the phenomenon better. Drawing upon the canvas of these two theoretical arguments, we further explore the factors affecting effectiveness scores, such as finance fundamentals (size, profitability, leverage, fixed assets and tangible assets) ${ }^{4}$, firm infection and firm location using regression models. We also test for the impact of medical digital technology on effectiveness via figure analyses. The procedures of our empirical analyses involve: (1) identifying the infectious period; (2) categorizing health policies as stringent or lax; (3) identifying how firms are affected by COVID-19 in a sector; (4) developing an expectation matrix to calculate health outcomes; (5) developing a leading indicator (effectiveness score) to investigate the effectiveness of policies; and (6) investigating the factors affecting effectiveness scores. It is also important to emphasize that we are also making a contribution methodologically by introducing a unique methodology which allows us to better estimate the effectiveness of health policies as well as their consequences on stock markets. Furthermore, we document a unique 'force majeure' that leads to lower energy demand, lower emissions and implicitly resulting in cleaner production (an extension to Klemeš et al., 1997).

The choice of China to conduct our experiment is based on the fact that Coronavirus

\footnotetext{
${ }^{3}$ As mentioned above, there are two research gaps: 1) so far, the effectiveness of such health policy implementation is yet to be analysed to understand how organizations and markets reacted during the period of the current pandemic; and 2) Although the health economics literature provides direct measures of health outcomes, such as recovery rates, these are lagging indicators, as opposed to leading indicators such as stock prices.

${ }^{4}$ Previous literature supports the relationship between finance fundamentals (Keim, 1983; Dische, 2002; Hull, 1999) and abnormal returns, which are used to calculate the effectiveness score.
} 
SARS-CoV-2 was first detected in Wuhan at the end of 2019 (Huang et al, 2020), and then had been found in the rest of the world ${ }^{5}$. By mid-February 2020, South Korea, Singapore, Taiwan and Japan followed the steps of China to contain and control the spread of the virus whilst by July 2021, almost every country introduced variations of these measures. China has been the first country to experience the effects of COVID-19 and our study aim to use this fertile soil to capture the first lessons learnt in terms of accountability/sustainability as it has major implications for the rest of the world that applied social distancing, lock down and return to work policies.

This paper is organised as follows. Section 2 offers a review of the existing literature whereas followed by description of data and methodology in section 3. In Section 4, the empirical results are presented and discussed. Section 5 is reserved for concluding remarks.

\section{Literature Review}

\subsection{Theoretical Underpinning}

Media Richness Theory has its roots grounded in information richness theory proposed by Daft and Lengel (1986). The theoretical cements in the idea of evaluating and using medium of communications amongst organizations and by organizations with other stakeholders. The theory states that all communication media differ in its ability to enable users to understand and react towards the information. Media is often considered a reflection of information which helps in converting unstructured data into a logical structure. Thus, media richness corresponds to the degree to which the raw data is processed to draw meaningful insights. The role of media becomes more critical when the degree of uncertainty is high and the flow of information is large (Rosenberry and Vicker, 2017). Media Richness Theory (MRT) helps in understanding this transformation better by comparing all the forms of media on a continuous scale and comparing them based on attributes of converting complex forms of data into simple form. Studies have discussed the power of media and MRT during situations like public administration (Chen et al. 2020), health care systems (Liao and Teng, 2018; Leek et al., 2016), crowdfunding (Yang et al., 2020; Behl et al., 2021), disaster relief operations, crises

5 We observe the information that later the COVID-19 has been found all over the world in the website of https://github.com/CSSEGISandData/COVID-19/ 
management (Chen et al., 2020; Behl et al., 2020) etc. Recent studies on the application of MRT indicate there exists a reliable organization public dialogic communication scale, which is mostly used while understanding organization-public communication (Yang et al., 2020; Behl et al., 2021; Behl et al., 2020). Most of the dialogic communication is between the government and the public during a disaster and most forms of media communication includes circulars, announcements, policies and notices. Such communication is spread across various forms of media like social media platforms, newspaper, radio, internet and telecom channels. Yang et al. (2021) further clarifies that the effectiveness of such media forms is often not studied in the case of any disaster. Another form of information communication that is prominent during disaster is between government and organizations like healthcare agencies, civil organizations, public development agencies, etc.

The inter-organizational communication, be it in the form of government to business or business to business or business to organization is mostly made using official channels like news channels, issuing circulars, and notifications on official websites. Most of such communication is not dialogic, however the receiver of the information is largely affected by most of these policy related decisions. Goldberg and Reed (2020) accounted that government policies impacted various business sectors. The global financial market risk has increased substantially in response to the current pandemic (Zhang et al., 2020). While some sectors like logistics, supply chain and tourism have been affected by the ongoing COVID-19, other sectors like healthcare and wellbeing have shown a positive growth. Thus, the same information and policy implications have helped some sectors to grow while others to suffer. Thus we can explain this phenomenon using contingency theory (CT). Galbraith (1977) argued that organizations must respond to new and changing environmental conditions, by redesigning their internal processing capabilities through structures and technologies (Tushman and Nadler, 1978; Lawrence and Lorsch, 1969). The theory assets that performance is not a result of any particular organizational design, but it is contingent on any appropriate match between organizational arrangements (For example: media and communication) and contextual variables.

Applying the contextual and theoretical background of MRT and CT in case of the ongoing COVID-19, it becomes interesting to calculate effectiveness score to evaluate the 
effectiveness score of these policies during COVID-19 on firms.

\subsection{COVID-19 and Sectoral Impacts}

The public health and medical literature is wide-ranging and offers rich evidence of how pandemics, such as the 2009 influenza virus (H1N2) developed, spread and how the containment and vaccination policies emerged (see e.g. review by Girard et al, 2010). The determinants and effects of such policies on the successful treatment of contagious viruses has also been a significant focus of the literature (Brien, Kwong and Buckeridge, 2012). In this regard, researchers and medical professionals have either used randomized control trials or in cases where this is not possible or unethical a key research design has been the quasiexperimental method of "Difference in Difference" which allows the study of causal relationships in various public health settings (see Wing et al., 2018). Other models that are used in the field of biology and epidemiology are exponential and logistic growth models to measure infection rates (Richards, 1959). Despite the realisation that any contagious virus has socio-economic implications on a society, which in turn impact on the speed of containment, there is limited research on this particular bi-directional relationship (Peckham, 2013).

From the macro-level perspective, one of the early studies that attempted to measure the macroeconomic impact of an influenza pandemic on the UK economy is by Keogh-Brown et al. (2010). They used epidemiological data of previous influenza pandemics and used sensitivity analysis using a macroeconomic model to give a range of GDP losses under mild and more extreme circumstances. In the context of the COVID-19, a recent study by Nicola et al. (2020) offers a general review of how the pandemic has impacted on different industries and sectors of the economy, ranging from the agricultural sector to the manufacturing and services sector. Although their study is of importance and contributes to our overall understanding of the impact of the pandemic on the world, it remains a "bird-eye" analysis of current developments.

Although these macro-level studies are exploring various impacts of the pandemic on society, there is limited discussion on how these impact specifically on the UNSDGs. "Grand challenges" such as the UNSDGs are seen as grand challenges that need to be overcome as a collective and inherently have significant managerial, policy and conceptual implications. 
Finding solutions to the series of UNSDGs has offered new insights for how individuals, firms and governments strategize, structure themselves and network with other stakeholders at different levels in order to become sustainable, which has been tested significantly since the recent global pandemic. Despite the many setbacks in countries around the world due to COVID19, there is renewed ambition to achieve the various UNSDGs that range from ending extreme poverty and hunger, inequality and injustice, gender inequality, improving education systems to tackling climate change and environmental protection.

However, the evidence at the firm-level is even more limited and links to how results relate to the UNSDGs is rarely discussed. A recent study by Alfaro et al. (2020) shows how unanticipated changes in COVID-19 infection rates predict US firm stock returns. They estimate that an unanticipated doubling of infections causes a fall of stock returns by 4 to 11 percent. Furthermore, they show that firms in industries associated with COVID-19 are more prone to such losses in stock prices and employment losses as a consequence.

Another recent study by Ding et al. (2020) explores the link between firm characteristics and stock prices in the first quarter of 2020 for over 6,000 firms across 56 countries. They find that stock prices were less affected for firms that had (a) stronger finance fundamentals in terms of cash, less debt and larger profits before the pandemic and (b) lesser exposure through global supply chains and customer locations (c) more CSR activities, and (d) less entrenched executives. On the other hand, stock price performance is worse for firms with greater hedge fund ownership, whereas firms with larger non-financial corporate ownership performed better.

Although these firm-level studies link the impact of COVID-19 to firm performance in terms of stock price or returns, the particularities of the pandemic are not further integrated into these analyses. In other words, countries and their health authorities have had their differences in how they are tackling the pandemic. Such nuances in containment policies are an important dimension and channel through which firms are impacted. Thus, this paper is the first to go beyond the firm-level characteristics and determinants in analysing the impact of COVID-19 by directly integrating into a model the announcements of health policies for COVID-19 in China and estimating its impact on firms via different channels.

In terms of the theoretical lens, this paper extends the application of the behavioural 
finance theories to the health policies concerning COVID-19. We utilise the insights from the efficient market hypothesis (Fama, 1970) and behavioural finance theories (Shleifer, 2000) in order to derive models to test the relationship between health policies to combat COVID-19 and the impact on firms. We contribute to the current debate on the repercussions on COVID19 by using a unique methodology ${ }^{6}$ to estimate the effectiveness of health policies as well as their consequences on stock markets.

The efficient market hypothesis is a traditional finance theory based on assumptions of how investors and markets should behave and argues that stock market participants react instantly to new information arrival and that prices reflect all available information (Fama, 1970). Therefore, any change is captured through abnormal returns on the first day of trading, and no further abnormal returns should be observed in the following days. However, behavioural finance attempts to explain actual investor and stock market behaviour and argues that (through conservatism bias) stock market participants have a tendency to adjust slowly to new information arrival (due to conservatism bias) leading to delayed interactions (see theoretical models by Barberis et al. 1998; Cumming, 2005; Hong and Stein, 1999; Moosa and Ramiah, 2017; Shleifer, 2000). Subsequently it is possible to observe significant abnormal returns days after the information has been released (i.e. under-reactions). There are numerous empirical studies in different contexts (see Cumming, 2005; Moosa and Ramiah, 2017; Ramiah et al., 2013).

This paper, therefore, contributes to the large literature of behavioural finance identifying the stock market's reactions to news and sentiments by extending it to the Covid19 pandemic and estimating the cumulative abnormal returns across different models and scenarios.

\section{Research Design}

\footnotetext{
${ }^{6}$ The efficient market hypothesis suggests that an efficient stock market is able to reflect all the information relevant in terms of abnormal stock returns and cumulative abnormal returns, such as the effects of those public policies released (say, those lockdown medical policies for the COVID-19). The behavioural finance theories show that investors may have delayed financial decisions and reactions due to their behaviour bias, which leads to delayed stock returns. As shown in the methodology part, according to the EMH and behavioural finance theories, abnormal stock returns are computed to estimate the effects of the medical policies for the COVID-19 (see the eighth paragraph in section 2.2 COVID-19 and sectoral Impacts on page 7).
} 


\subsection{Data Collection and Sample Description}

To capture the SDG 3 in terms of healthy nations, we investigate the announcements of health policies for COVID-19 in China. We initially collected 14 announcements from the website of the National Health Commission ${ }^{7}$ of the People's Republic of China. One announcement is excluded as the Chinese stock markets were closed during the Spring Festival holidays. We are unable to use seven more announcements as there were multiple announcements within five days. Our final list consists of six announcements ${ }^{8}$ consisting of one announcement on the prevention and control policy, two announcements about returning to work policies and three announcements about diagnosis policies (see Appendix I, Panel A).

As the social distancing measures did not allow us to collect primary in the initial stages of the pandemic, we used readily available financial data that was collected from the Chinese stock markets and the Accounting Research (CSMAR) database and it covers the infectious period of the COVID-19. Our sample includes A shares from the Shanghai Stock Exchange (SHSE) and the Shenzhen Stock Exchange (SZSE). In total, we have 5,274 observations from 1,025 firms.

\subsection{Measuring the Market Reactions to the COVID-19 Policies}

Event study methodology (Brown and Warner, 1985) is used to estimate the market reactions to the announcements of health policies (SDG 3). More specifically, the Market-adjusted Return Model (Brown and Warner, 1985) is used to calculate cumulative abnormal returns ${ }^{9}$ $\left(C A R_{i t}\right)$ around the announcements of health policies using the event windows of $(-1,+1),(-$

\footnotetext{
${ }^{7} \mathrm{http}: / /$ www.nhc.gov.cn/

${ }_{8}^{7}$ As shown in the Appendix I, these six announcements are very significant for the situation of spreading COVID-19 in China. 2020/01/22 is the date when the Program of the Prevention and Control of 2019-nCoV (2nd edition) was released, which is followed by the Wuhan quarantine, marking the beginning of the prevention and control of COVID-19 in China. 2020/02/05 is also significant, as from 2020/02/05, all the suspected cases of COVID-19 were required to be included as confirmed cases and should be sent to hospitals as many as possible, which reflects the strong executive force of controlling the pandemic in this country. 2020/02/22 and 2020/03/07 are significant as they are the dates for residents to go back to work. Theses dates are selected to appropriately show the effectiveness of health policy implementation to understand how organizations and markets reacted during the period of the current pandemic. In fact, these dates are decided cautiously by experts and these policies for going back to work are always implemented considering the prevention and control of COVID-19 in China and are able to contribute to national production effectively without increasing the confirmed cases for the pandemic. 2020/03/13 and 2020/03/18 are significant as they reflect the new actions and reactions of Chinese government taken when residents go back to work and new situation of COVID-19 occurs (for instance, when university students go back to their schools, overseas travellers are coming, etc.) It is usual to analyse the effect of only one announcement. As mentioned above, these six announcements are significant, they are enough for our valid findings.

${ }^{9}$ We use the buy and hold model (Ikenberry et al., 1995) to calculate cumulative abnormal returns, and we conduct several empirical analyses as robustness tests. We choose not to use the CAPM model to compute expected returns as according to Zhang and Meng (2013), CAPM is not appropriate for Chinese stock markets.
} 
$2,+2),(-3,+3)$ and $(-5,+5)$ as these event windows have been widely accepted in the finance literature (Peng et al., 2011; Liu and Tian, 2012; Jiang et al., 2015; Yang et al., 2018). These windows allow us to capture any leakage and/or any delayed response. We assume the market reactions to the announcements of policies (in terms of cumulative abnormal returns) have the potential to capture the impacts of policies on firm operations as these market reactions are the reflection of investors' expectations.

The Market-adjusted Return Model can be written as follows:

$$
A R_{i t}=R_{i t}-R_{m t}+\varepsilon_{i t}
$$

where $A R_{i t}$ refers to the abnormal return for firm $i$ at time $t ; R_{i t}$ is the daily return for firm $i$ at time $t ; R_{m t}$ stands for the market return at time $t$ and $\varepsilon_{i t}$ is the error term.

\subsection{Measuring the Effectiveness of Implementing the COVID-19 Policies}

We develop a systematic process to arrive at a measure of the effectiveness of health policies, namely: (1) identifying the infectious period; (2) categorizing health policies as stringent or lax; (3) determining whether a sector is regarded as either a COVID-Plus or COVID-Minus; (4) estimating the market reactions to health policies in terms of cumulative abnormal returns around the announcement dates; and (5) developing effectiveness scores based on cumulative abnormal returns.

The first step of measuring effectiveness scores involves the identification of the infectious period, which follows the shape of a curve as shown in Figure 1. The first part of the curve represents the exponential growth period and the second part of the curve illustrate the flattening the curve period. In the early stages of an epidemic, the virus can spread from one individual to another, leading to an increase in the number of affected cases and this is referred to as the exponential growth period. After some policies are introduced to control the virus, the spread slows down and this is referred to as flattening the curve period. During this period, production is expected to slow down and this leads to better air quality and this is in alignment with SDG 11: Sustainable Cities and Communities. Figure 1 clearly shows the infectious period 
which is evidently disaggregated into the exponential growth period and flattening the curve period for China.

We identify two milestones of the infectious period and they are shown in Appendix I, Panel B. The first period was on the $23^{\text {rd }}$ January 2020, whereby Wuhan was placed under effective quarantine and which marks the turning point of the Chinese epidemic prevention campaign (Vulcan Mountain Hospital, Raytheon Mountain Hospital, and cabin hospitals were introduced for people affected with the virus). The number of patients diagnosed and cured surged over a short time period as clearly illustrated by the exponential growth period of Figure 1. The second period is identified as the $10^{\text {th }}$ February 2020, where under the joint efforts of hospitals, firms and all residents, China reached the inflection point of the epidemic successfully ${ }^{10}$. These measures are consistent with SDG 3 which is about Good Health and Well-Being. Chinese residents returned to work after the Spring Festival holiday as scheduled after President Xi Jinping appeared to the public for the first time since the epidemic began by visiting a hospital in Beijing and urging Chinese residents to fight the battle against the virus with confidence. Following the leader's appearance, we notice that virus has been under control as evidenced by a decreasing trend (see Figures 1, 2, 3 and 4). Following these events, China reached its flattening the curve period (see Figure 1).

The next step of measuring effectiveness is to identify health policies as stringent or lax, with the policies being stringent if they assist to maintain home quarantine, restrict firm activities to control for the spread of the virus, and increase patients cured from COVID-19. We classify a returning to work instruction as a lax policy. It is worth noting that although the policy is regarded as lax, it still emphasizes the importance of prevention and control to fight the battle against the virus. In our analysis, four announcements are stringent and two of them are lax (see Appendix I, Panel A). The stringent and lax policies are in accordance with SDG 8 that refers to Decent Work and Economic Growth.

The third step is to categorize firms and industries as either COVID-Plus or COVIDMinus on the assumption that the health policies undertaken are stringent. For example, the real estate sector (including the constituents) is classified as a COVID-Minus as it is expected

\footnotetext{
${ }^{10}$ The date to resume to work was decided by local governments following scientific advice.
} 
to be negatively affected following health policies such as home quarantine, whereby buyers and sellers are unable to complete house purchases. In contrast, we classify the IT sector as a COVID-Plus sector as this sector is positively affected by home quarantine with the number of network users soaring as a result of communication needs and home entertainment. The IT sector is an example where we capture SDG 9- Industry, Innovation and Infrastructure. We expect a reverse effect to occur when the home quarantine ban is lifted and the opposite is expected for lax policies. We report our expectation matrix in terms of COVID-Plus and COVID-Minus for all sectors in Appendix II where we find 14 COVID-Minus and five COVID-Plus. The sectoral analyses enable us to detect whether other SDGs have been achieved.

The fourth step is to compute cumulative abnormal returns around the announcement dates of health policies. Daily returns for each sector are calculated as the first natural logarithmic difference of stock price index for all individual firms. We then calculate expected returns with the Market-adjusted Return Model (Equation 1) using the event study methodology (Brown and Warner, 1985). Following Watts (1978), we define abnormal returns as the difference between actual and expected returns. Average sector cumulative abnormal returns are calculated by grouping individual firms' cumulative abnormal returns into sectors.

The fifth step is the construction of effectiveness scores, representing one of the methodological contributions of this paper. The underlying assumption is that these policies have the potential to either ${ }^{11}$ negatively or positively affect the cost and revenue functions of most Chinese firms during both the exponential growth and flattening the curve periods. For example, during the exponential growth period, the real estate sector is negatively affected by prevention and control policies (in terms of home quarantine) due to decreasing customers and sales, which in turn negatively affects its revenue function. The reverse is expected for the flattening the curve period.

This step of measuring effectiveness involves the examination of cumulative abnormal returns of listed firms $(i)$ within sector $(j)$ on the days when policies $(p)$ are announced. For a measure to be regarded as effective for COVID-Minus, we expect a negative cumulative abnormal returns in the exponential growth period and/or a positive cumulative abnormal

\footnotetext{
${ }^{11}$ Note that another possibility is that a sector is not affected by these measures.
} 
returns in the flattening the curve period. We expect the reverse for COVID-Plus sectors. Firms and sectors may implement policies less effectively (or ineffectively) as they still have to operate to maintain the daily life of Chinese residents, in terms of basic finance, utility and limited transportation in the period of quarantine. The sector-level effectiveness (the proportion of firms where the policies are effective) is measured as

$$
E F C A R_{j p}=\frac{N E_{j p}}{N j}
$$

where $E F C A R_{j p}$ is the effectiveness for sector $j$ following the announcement dates of policies $p, N E_{j p}$ refers to the number of firms where the policy is effective within a sector, and $N j$ stands for the total number of firms in sector $j$. Standard t-statistics of effectiveness are calculated to measure statistical significance. We argue that the effectiveness measure is a proxy for the measure of cleaner production of basic necessities in that the pollution level is reduced significantly while the production of basic necessities continues.

\subsection{Regression Methodology}

A systematic regression methodology is used to investigate the effectiveness of health policies in this paper. We use the entire sample to investigate the factors affecting the market reactions of health policies in terms of cumulative abnormal returns. We examine the effects of the quarantine of Wuhan and work-resumption policies in the exponential growth and flattening the curve periods using interaction terms and then we investigate the factors affecting (1) market reactions as measured by cumulative abnormal returns and (2) effectiveness as measured by effectiveness scores via separate samples.

\subsection{Model Specification}

The effects in terms of cumulative abnormal returns (CAR) and effectiveness following the announcements of policies are investigated with respect to finance fundamentals (Financials), firm infection which is represented by firms being affected by COVID-19 (Infection) and location (Location). Financials includes firm size, profitability, leverage, fixed assets and intangible assets; Infection includes COVID-Plus and COVID-Minus; and Location includes the place which is next to Hubei (NTH), or in Beijing, Shanghai, Guangdong, Chongqing and 
Tianjin $(B S G C T)$ and Hubei $(H B)$. It is worth mentioning that the purpose of introducing the variable Location is to empirically test for the effects of SDG 11-Sustainable Cities and Communities.

The equation for how market reaction $(C A R)$ is affected by finance fundamentals, firm infection and location is specified as:

$$
\begin{gathered}
\mathrm{CAR}_{j p}=\alpha_{j p}+\sum_{f=1}^{5} \beta_{j p} \text { Financials }_{j p}+\sum_{i=1}^{2} \gamma_{j p} \text { Infection }_{j p}+ \\
\sum_{l=1}^{3} \delta_{j p} \text { Location }_{j p}+\varepsilon_{j p}
\end{gathered}
$$

where $C A R_{j p}$ refers to the cumulative abnormal returns for each sector $j$ following the health

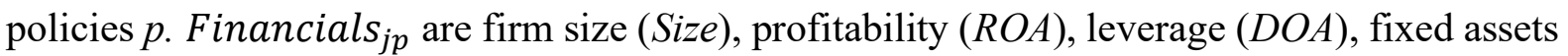
(Fixed Assets) and intangible assets (Intangible). Size refers to the natural logarithm of total assets, $R O A$ stands for the ratio of net income to total assets, $D O A$ is the total liabilities divided by total assets, Fixed Assets refer to the total fixed assets divided by total assets, and Intangible is the ratio of total intangible assets to total assets. Infection Ip $_{p}$ is represented by COVIDPlus $_{j p}$ which is a dummy variable taking the value of 1 if a sector is a COVID-Plus and 0 otherwise. This variable is expected to be positively affected by home quarantine and negatively affected after home quarantine. When COVIDPlus ${ }_{j p}$ equals 0 , it implicitly assumes the sector is a COVID-Minus. Location jp $_{p}$ is represented by three variables, $N T H, B S G C T$ and $H B . N T H$ is a dummy variable that takes the value of 1 if a city or province where a firm locates is next ${ }^{12}$ to Hubei, and 0 otherwise. BSGCT, a dummy variable, equals 1 if a city/province where a firm is located is Beijing, Shanghai, Guangdong, Chongqing or Tianjin, and 0 otherwise. These locations are either municipalities that are directly under the central government or are first-tier cities with higher local GDP. $H B$, which is a dummy variable, takes the value of 1 if a city/province where a firm locates is Hubei, and 0 otherwise. We expect a negative relationship with $N T H$ and $H B$ as more patients were diagnosed in these locations. We posit that negative abnormal returns are to be expected in locations where more people are

\footnotetext{
${ }^{12}$ Some cities or provinces were exposed to the outflow of people from Hubei before the quarantine of Wuhan, which leads to the higher pressure of patients diagnosed in other locations such as Henan, Shaanxi, Chongqing, Hunan, Jiangxi and Anhui. Henan, Shaanxi, Hunan, Jiangxi and Anhui are provinces and Chongqing is a municipality directly under central government. The information on the number of outflow of people from Hubei and the other cities/provinces are released by the official organizations in China every day before the $12^{\text {th }}$ March 2020. It should be noted that from the $12^{\text {th }}$ March, the related organization started to release the information on the imported confirmed patients from overseas.
} 
diagnosed. On the other hand, we expect a positive relationship with BSGCT as more patients recovered in these locations. Industry-fixed effects are also considered in the analyses and we provide variable descriptions in Appendix III.

The sector-level effectiveness is explained by the following equation:

$$
\begin{gathered}
\operatorname{EFCAR}_{j p}=\alpha_{j p} \sum_{f=1}^{5} \beta_{j p} \text { Financials }_{j p}+\sum_{i=1}^{2} \gamma_{j p} \text { Infection }_{j p}+ \\
\sum_{l=1}^{3} \delta_{j p} \text { Location }_{j p}+\varepsilon_{j p}
\end{gathered}
$$

where $E F C A R_{j p}$ is the effectiveness scores computed using cumulative abnormal returns. We expect a negative (positive) relationship with $N T H$ and $H B(B S G C T)$ due to the more patients diagnosed (cured) in/next to Hubei (BSGCT) and we assume this leads to negative (positive) effectiveness.

\subsection{Summary Statistics}

Table 1 shows the summary statistics for the main variables in our analysis. As shown in Panel A of Table 1, on average, cumulative abnormal returns are 0.0002, 0.0003, 0.0001 and -0.0007 across the event windows of $(-1,+1),(-2,+2),(-3,+3)$ and $(-5,+5)$, respectively. The minimum and maximum values of cumulative abnormal returns are -0.3246 and 0.5077 , respectively and this indicates significant cumulative abnormal returns are associated with the announcements we cover in this study. The mean values of the finance fundamentals are $22.7369,0.6861$, 0.4267, 0.2164 and 0.0487 for firm size, profitability, leverage, fixed and intangible assets, respectively. The mean values for $N T H, B S G C T$ and $H B$ are $0.1221,0.3549$ and 0.0264 , respectively, and this indicates that $12.21 \%, 35.49 \%$ and $2.64 \%$ of firm-year observations are located next to Hubei, in BSGCT cities and in Hubei. This geographical result contributes to discussion around SDG 11 (Sustainable Cities and Communities) in that cities are hubs for commerce, culture, science, productivity, social, human and economic development.

\section{(Insert Table 1 here)}

Panel B of Table 1 shows the summary statistics for the exponential growth sample. Compared to the results in Panel A, cumulative abnormal returns for the exponential growth sample are much lower, with cumulative abnormal returns being $-0.0010,-0.0019,-0.0014$ and -0.0012 across the event windows of $(-1,+1),(-2,+2),(-3,+3)$ and $(-5,+5)$, respectively. The 
effectiveness scores for the exponential growth sample are $0.5365,0.5252,0.5292$, and 0.5207 for $\operatorname{EFFCAR}(-1,+1), \operatorname{EFFCAR}(-2,+2), \operatorname{EFFCAR}(-3,+3)$ and $\operatorname{EFFCAR}(-5,+5)$. Our results indicate that more than half of firms in our sectors implemented the policies effectively during the exponential growth period. One of the possible explanation for why the remaining half were less compliant is because they had to continue to operate to provide the necessities during that period. We postulate that the production of these basic necessities were conducted in an environment where pollution was reduced significantly in China-hence representing a cleaner production state for basic necessities.

In contrast, cumulative abnormal returns for the flattening the curve sample (see Table 1, Panel C) are higher than those of the full sample, whilst effectiveness scores are lower compared with the exponential growth sample. The cumulative abnormal returns show that as time passes, the effects of COVID-19 on the stock market become larger whilst our findings about the effectiveness scores suggest that more businesses have to be able to join the marketperhaps by adopting new technologies in terms of online platforms. The evidence provided within the exponential growth and flattening the curve are our unique contribution to the SDG 3 (Good Health and Well-Being) which refers to ensuring healthy lives and promote well-being for all at all ages during the COVID-19 period.

\section{(Insert Table 2 here)}

Table 2 shows the results of test of difference in mean of $C A R$ and effectiveness scores. We can see from the Panel A that COVID-Minus tends to experience higher magnitude of cumulative abnormal returns than COVID-Plus in full sample, namely the $C A R(-2,+2)$ and CAR $(-3,+3)$. This asymmetry is statistically significant at the $5 \%$ and $10 \%$ level of significance. Moreover, our results of effectiveness show that COVID-Minus sectors are able to implement policies more effectively in the exponential growth period and to a lesser degree during the flattening the curve period (see Table 1, Panel B and C).

\subsection{Summary of the Methodology}


The methodology used in this paper can be summarised in the following processes: 1) downloading the publicly available announcements about COVID-19 policies and financial data series from reliable databases; 2) applying event study methodology to capture the market reaction of those COVID-19 policies; 3) using the five step procedure to measure the effectiveness of implementing the COVID-19 policies; and 4) using regression analysis to identify the factors affecting the effectiveness of the policies.

\section{Empirical Results}

\subsection{The Analyses of Market Reactions}

The fourth step of developing the effectiveness scores involves the calculation of cumulative abnormal returns around the announcement dates of policies. Table 3 reports the results of average cumulative abnormal returns by events. We can see from Table 3 that the first policy for prevention and control (policy in relation to SDG 3) generates the lowest return, while the fourth policy of returning to work (policy in relation to SDG 12-Ensure sustainable consumption and production patterns) leads to the highest return. This result implies that the appearance of COVID-19 significantly negatively affects stock markets, whilst the government support for work resumption and production improves investors' confidence.

\section{(Insert Table 3 and 4 here)}

Table 4 shows the results of average cumulative abnormal returns by sectors for all samples. The results in Table 4, Panel A indicate that policies affect COVID-Minus sectors negatively in the full sample, resulting in negative abnormal returns for sectors, such as education (SDG 4-ensuring inclusive and equitable quality education and promote lifelong learning opportunities for all), real estate (SDG 11) and retailing (SDG 12) and such impacts tend to be more evident with longer window periods. Compared with the results in the full sample, the negative impacts are more profound in the exponential growth period (Table 4, Panel B) for COVID-Minus sectors, such as retailing and utility.

On the contrary, for the COVID-Plus sector, such as the financial sector tends to experience positive cumulative abnormal returns in this time period. As shown in Table 4, Panel $\mathrm{C}$, the negative influences of policies become insignificant in the flattening the curve period 
for most of COVID-Minus sectors, such as retailing and utility (SDG 6: ensuring availability and sustainable management of water and sanitation for all and SDG 7: ensuring access to affordable, reliable, sustainable and modern energy for all), due to the resumption of work. In contrast, the negative impacts for the education sector are more evident in this time period, as the education sector tends to behave in a unique manner during the epidemic. Our results are consistent with the (1) winter school vacation (23rd of January to mid-February 2020) and (2) the returning to work date of $10^{\text {th }}$ February 2020.

\section{(Insert Table 5 here)}

\subsection{The Analyses of Effectiveness}

Effectiveness scores, as measured by cumulative abnormal returns, are calculated for our events and sectors. Table 5 shows the mean effectiveness scores for the events we investigate and the scores vary between 0.5499 and 0.4335 . We can see from Table 5 that the first health policy for prevention and control achieves the highest effectiveness scores, while the third health policy of returning to work results in the lowest effectiveness scores. The empirical results reflect the remarkable efforts of China to control the epidemic (SDG 3) and our findings have serious implications for other countries as it implicitly shows the percentage of activities to be conducted to keep an economy afloat (SDG 8: promoting sustained, inclusive and sustainable economic growth, full and productive employment and decent work for all).

\section{(Insert Table 6 here)}

Table 6 reports the average effectiveness for different sectors. For instance, the mean effectiveness scores for the manufacturing sector (COVID-Minus) are 0.5485, 0.5405, 0.5459, and 0.5423 across the event windows of $(-1,+1),(-2,+2),(-3,+3)$ and $(-5,+5)$ (see Table 6 , Panel A). This implicitly implies that $54.85 \%, 54.05 \%, 54.59 \%$ and $54.23 \%$ of firms in this sector are able to comply with COVID-19 policies effectively during the exponential growth period (SDG 8). Implicitly, these results show the proportion of cleaner production (SDG 11). The mean effectiveness score for the utility sector are much lower and they are $-0.2679,0.3036$, 0.3750 and 0.3036 across the event windows of $(-1,+1),(-2,+2),(-3,+3)$ and $(-5,+5)$. This is consistent with the notion of essential sectors must continue to produce during the epidemic period. As a COVID-Plus sector, the IT sector achieves the highest effectiveness as a result of 
increasing communication needs and internet usage. The financial sector performs well due to continuing financial assistance provided for firms and individuals during this difficult period of reduced business activities. In general, we find that COVID-Minus sectors implement policies more effectively during the exponential growth period and less so during the flattening the curve period (see Table 6, Panel A and B).

\subsection{Factors Affecting Market Reactions}

Table 7 exhibits the factors that influence the market reactions of health policies (SDG 3) in terms of cumulative abnormal returns. In the full sample as shown in Panel A of Table 7, we find four factors with statistical significance namely Size, ROA, Intangible and Infection. Size and intangible assets (profitability) are negatively (is positively) associated with cumulative abnormal returns, implying that the revenue functions of diverse firms/sectors are significantly affected by policies in the full sample. Our results suggest that larger organizations were more affected as their costs of compliance and loss of business tend to be higher than those of small firms. The findings of the profitability variable suggest that profitable firms were less (negatively) affected than unprofitable ones. According to our results, financial fundamentals provide useful information as to how a firm was affected by COVID-19. Furthermore, we find geographical location in terms of being located near or in Hubei has no serious implications. The above empirical analyses are repeated using alternative event windows and firm-fixed effects to control for delayed response, the effects of multiple announcements and firm-specific information within five days. We find the results in Table 7, Panel B and C are similar to those in Table 7, Panel A and this provides additional robustness of our findings.

Panel D of Table 7 shows the results related to the effects of prevention and control policies (the quarantine of Wuhan). A dummy variable, Block, is employed to measure the quarantine of Wuhan, which equals 1 if the observation occurs after the quarantine of Wuhan, and 0 otherwise. According to the results in Table 7, Panel D, we find that the estimated coefficients of Block and the interaction term of Infection and Block are all positive-implying the stock market welcomed the quarantine measure of Wuhan and it represents a turning point in the Chinese epidemic prevention campaign.

The effects of the quarantine of Wuhan have led to a structural change in the lifestyle 
of the Chinese population (SDG 3). For example (1) online entertainment (online video game and short video platform) became more popular; (2) citizens watched online real-time tracking of the epidemic and hospital constructions (see Figure 7); (3) online dining and shopping businesses boomed (see Figure 5); (4) online education and training platform were used as part of the business continuation plan (see Figure 6); (5) online healthcare facilities gained momentum (see Figures 7 to 9); (6) online offices were used extensively (see Figure 10) and (7) less production leads to less pollution (see Figure 11) ${ }^{13}$. The online innovations are in alignment with SDG 9 which is about building resilient infrastructure, promote inclusive and sustainable industrialization and foster innovation.

\section{(Insert Table 7 here)}

We also investigate the effects of work-resumption policies after the $10^{\text {th }}$ February 2020. We use a dummy variable, work, which equals 1 if the observation occurs after the return-towork time, and 0 otherwise. The empirical results in Table 7, Panel E indicate that the impact of Work is insignificant. We repeated the analyses for the exponential growth and flattening the curve periods and found similar results (Table 7, Panel F and G).

\subsection{Factors Affecting Effectiveness}

Table 8 shows the factors affecting the effectiveness scores of the health policies we investigate. Table 8, Panel A, shows that the estimated coefficients of size and fixed assets are negative in the exponential growth sample, indicating that firm with smaller size (and/or lower) fixed assets implement prevention and control policies more effectively as they may attempt to follow home quarantine and restrict business operations to avoid costs and penalties. In this instance, we illustrate how size and fixed assets are related to cleaner production. The estimated coefficients of Infection are negative in the exponential growth sample, indicating that COVID-Minus sectors tend to comply with health policies effectively. The coefficients of BSGCT are positive-implying that cities/provinces with higher local GDP and better medical sources have more resources to combat the virus.

\section{(Insert Table 8 here)}

\footnotetext{
${ }^{13}$ Recent studies, such as Xiao et al. (2020) suggest that the subway development contributes to more air pollution, while Zeng et al. (2021) and Wang and Zhou (2021) show the spatial impact of air pollution in China.
} 
Panel B of Table 8 reports the factors that contribute to the effectiveness scores in the flattening the curve period. The coefficients of size are negative in this sample-indicating that smaller firms implement health policies more effectively (cleaner production). The estimated coefficients of Infection are positive, suggesting that COVID-Plus sectors comply with policies more effectively. COVID-Minus sectors engage in the resumption to work and production less effectively and this may be due to continuous quarantine and decreasing work force. In contrast, the coefficients of NTH are negative. This indicates that cities and provinces that are next to Hubei are still facing strong restrictions in terms of epidemic prevention and control and are unable to resume work and production until March 2020. Similar to the exponential growth sample, the coefficients of $B S G C T$ are positive.

Overall, the above results can be summarized in Table 9, where we show how each set of results are linked to the various UNSDGs.

\section{(Insert Table 9 here)}

\section{Implications of the Study}

The policy outcomes emanating from the results of our study are that COVID-19 policies impacted on eleven out of the seventeen UNSDGS in China and in that sense COVID-19 measures have contributed to the sustainable future of China. Although the limitations of our study is that it a single country context analysis, tThe implications are that other countries which introduced these measures are very likely to have contributed to the sustainability of their nations and more countries, specific studies must be conducted to document these effects. This offers the opportunity for future research in this area and other country contexts.

The managerial implications of our study are that there is a significant difference amongst SMEs versus larger firms, firms in different industries and sectors as well as firms in different regions of China. Knowing and anticipating the strains and challenges that COVID has brought and future crisis may bring again, needs to be taken seriously by managers, industry representatives and government officials and policy makers. This means that firms in general need to become more resilient and agile but also anticipate such grand challenges in order to step in to support the infrastructure that is needed to overcome such crisis moments that affects 
and spills over different dimensions of the social, economic and political sphere of a nation that is on a quest to not only overcome the crisis but to come out of it stronger in terms of sustainability outcomes. This can only occur in an eco-system, where the public and private sectors work together and are supported by appropriate and timely government policies. We, therefore, can draw the important general conclusion that despite the unfortunate casualties of COVID-19, the measures undertaken (social distancing, lock down and return to work policies) around the world have contributed to the sustainability of the world. At the same time, more insights to the understanding and managing of solutions is required.

The study contributes to the media richness theory and cements the idea of using the right communication channels to disseminate information during and after COVID 19 especially for healthcare policies. Most of the earlier use of MRT is to explain the role of communication and technology in contexts that are not dialogic in nature. Thus, the after effects of policies on the stock market further extends the contingency theory and its relation with media richness theory. The inter organizational communication has various forms, COVID 19 draws emphasis on government to business communication as the most important piece. One of the critical ways government communicate with firms is issue of ordinances, policies, passing bills and amending acts. Thus, while most of the communication follows a legal language, it is also important to note that such orders and forms of communication are information rich. Our study uses this rich form of media to explain how these impact the financial performance of firms listed on stock exchange. Thus, the study extends how CT and MRT to calculate the effectiveness scores and evaluate them for understanding firm performance better.

\section{Conclusion, Limitations and Future Scope of the study}

The objective of health regulation for COVID-19 is to stop the spread of the virus. Following the announcement of the virus by the World Health Organisation, countries around the world have been implementing a series of health related policies to address the problem of its spread. Although most health policies that emerged during the period of COVID-19 are stringent, certain lax policies are subsequently introduced to relax previous regulations. One major issue 
that the world faces in regards to health regulation is that we do not have a leading indicator to determine the effectiveness of health policies.

This paper contributes to this current debate by using a unique methodology to estimate the effectiveness of health policies as well as their consequences on stock markets. With our newly developed methodology, we provide strong empirical evidence to establish key determinants of the effectiveness of health policies, such as financial indicators, how firms are affected by the regulations surrounding COVID-19 and geographical location of a firm. In this way, we are able to document in detail how the Chinese economy has fared during the COVID19 crisis.

The results of our study suggest that the measures undertaken by the Chinese government to control the COVID-19 pandemic are clearly in alignment with SDG 1: No Poverty; SDG 2: Zero Hunger; SDG 3: Good Health and Well-Being; SDG 4: Quality Education; SDG 6: Clean Water and Sanitation; SDG 7: Affordable and Clean Energy; SDG 8: Decent Work and Economic Growth; SDG 9: Industry, Innovation and Infrastructure; SDG 11: Sustainable Cities and Communities; SDG 12: Responsible Consumption and Production; and SDG 13: Climate Action.

Nonetheless, one of the limitations of our study is methodological in nature in the sense that it relies on the expectations of market participants and is implicitly assuming that the market is efficient (efficient market hypothesis is holding). Another limitation is that we exclusively used quantitative research techniques to analyse this research topic. Future research may be able to uncover more detailed and nuanced insights into the many relationships among stakeholders when using more qualitative research techniques once it is safer to do so.

\section{References}

Alfaro, L., Chari, A., Greenland, A. N., \& Schott, P. K. (2020). Aggregate and firm-level stock returns during pandemics, in real time (No. w26950). National Bureau of Economic Research.

Barberis, N., Shleifer, A., \& Vishny, R. (1998). A model of investor sentiment, Journal of 
Financial Economics, 49(3), 307-343.

Behl, A., Dutta, P., Luo, Z., \& Sheorey, P. (2021). Enabling artificial intelligence on a donationbased crowdfunding platform: a theoretical approach. Annals of Operations Research, 129.

Behl, A., Dutta, P., Sheorey, P., \& Singh, R. K. (2020). Examining the role of dialogic communication and trust in donation-based crowdfunding tasks using information quality perspective. The TQM Journal.

Brien, S., Kwong, J. C., \& Buckeridge, D. L. (2012). The determinants of 2009 pandemic A/H1N1 influenza vaccination: a systematic review. Vaccine, 30(7), 1255-1264.

Brown, S. J., \& Warner, J. B. (1985). Using daily stock returns: The case of event studies. Journal of Financial Economics 14 (1): 3-31.

Chen, Q., Min, C., Zhang, W., Wang, G., Ma, X., \& Evans, R. (2020). Unpacking the black box:

How to promote citizen engagement through government social media during the COVID-19 crisis. Computers in Human Behavior, 110, 106380.

Cumming, D. J. (2005). Agency costs, institutions, learning, and taxation in venture capital contracting. Journal of Business Venturing, 20(5), 573-622.

Daft, R. L., \& Lengel, R. H. (1986). Organizational information requirements, media richness and

structural design. Management Science, 32(5), 554-571.

Ding, W., Levine, R., Lin, C., \& Xie, W. (2020). Corporate immunity to the COVID-19 pandemic (No. w27055). National Bureau of Economic Research.

Dische, A. (2002). Dispersion in analyst forecasts and the profitability of earnings momentum strategies. European Financial Management, 8 (2): 211-228.

Fama, E. F. (1970). Efficient capital markets: A review of theory and empirical work. The Journal of Finance, 25(2), 383-417.

Galbraith, J. R. (1977), Organization Design, Reading, MA: Addison-Wesley Publishing Co

Girard, M. P., Tam, J. S., Assossou, O. M., \& Kieny, M. P. (2010). The 2009 A(H1N1) influenza virus pandemic: A review. Vaccine, 28(31), 4895-4902.

Goldberg, P. K., \& Reed, T. (2020). The effect of the coronavirus pandemic in emerging market 
and developing economies an optimistic preliminary account. BROOKINGS. Washington, DC: Brookings. Available at: from https://www.brookings.edu/bpea-articles/the-effectsof-the-coronavirus-pandemic-in-emerging-market-and-developing-economies/

Hong, H., \& Stein, J.C. (1999). A unified theory of underreaction, momentum trading and overreaction in asset markets, Journal of Finance, 54(6), 2143-2184.

Huang, C., Wang, Y., Li, X., Ren, L., \& Cao, B., (2020). Clinical features of patients infected with 2019 novel coronavirus in Wuhan, China. The Lancet, 395.10223: 497-506.

Hull, R. M. (1999). Leverage ratios, sector norms, and stock price reaction: An empirical investigation of stock-for-debt transactions. Financial Management, 28 (2): 32-45.

Ikenberry. D., Lakonishok. J., \& Vermaelen. T. (1995). Market underreaction to open market share repurchases. Journal of Financial Economics 39(2-3), 181-208.

Jiang, G., Rao, P., \& Yue, H. (2015). Tunnelling through non-operational fund occupancy: An investigation based on officially identified activities. Journal of Corporate Finance 32, $295-311$.

Keim, D. B. (1983). Size-related anomalies and stock return seasonality: Further empirical evidence. Journal of Financial Economics, 12 (1): 13-32.

Keogh-Brown, M. R., Wren-Lewis, S., Edmunds, W. J., Beutels, P., \& Smith, R. D. (2010). The possible macroeconomic impact on the UK of an influenza pandemic. Health economics, 19(11), 1345-1360.

Klemeš, J., Dhole, V., Raissi, K., Perry, S., \& Puigjaner, L. (1997). Targeting and design methodology for reduction of fuel, power and $\mathrm{CO} 2$ on total sites. Applied Thermal Engineering 17(8-10), 993-1003.

Lawrence, P., \& Lorsch, J. (1969). Organization and Environment, Homewood, IL: Irwin

Leek, S., Canning, L., \& Houghton, D. (2016). Revisiting the Task Media Fit Model in the era of

Web 2.0: Twitter use and interaction in the healthcare sector. Industrial Marketing Management, 54, 25-32.

Liao, G. Y., \& Teng, C. I. (2018). How Can Information Systems Strengthen Virtual Communities? Perspective of Media Richness Theory. In PACIS (p. 34).

Liu, Q., \& Tian, G. (2012). Controlling shareholder, expropriations and firm's leverage decision: 
Evidence from Chinese non-tradable share reform. Journal of Corporate Finance 18(4), 782-803.

Moosa, I. A., \& Ramiah, V. (2017). Financial Consequences of Behavioural Biases. Palgrave Macmillan.

Nicola, M., Alsafi, Z., Sohrabi, C., Kerwan, A., Al-Jabir, A., Iosifidis, C., ... \& Agha, R. (2020). The socio-economic implications of the coronavirus pandemic (COVID-19): A review. International Journal of Surgery, 78.

Peckham, R. (2013). Economies of contagion: financial crisis and pandemic. Economy and Society, 42(2), 226-248.

Peng, V.Q., Wei, K.C.J., \& Yang, Z., (2011). Tunnelling or propping: Evidence from connected transactions in China. Journal of Corporate Finance 17(2), 306-325.

Ramiah, V., Martin, B., \& Moosa, I. (2013). How does the stock market react to the announcement of green policies? Journal of Banking \& Finance, 37(5), 1747-1758.

Richards, F. J. (1959). A Flexible Growth Function for Empirical Use. Journal of Experimental Botany, 10(2), 290-301.

Rosenberry, J., \& Vicker, L. A. (2017). Applied mass communication theory: A guide for media practitioners. Routledge.

Shleifer, A. (2000). Inefficient markets: An introduction to behavioural finance (Oxford University Press).

Tushman, M. (1978). Technical Communication in R\&D Laboratories: The Impact of Project Work Characteristics. Academy of Management Journal, 21, 624-645.

Wang X., \& Zhou, D., (2021). Spatial agglomeration and driving factors of environmental pollution: A spatial analysis. Journal of Cleaner Production, 279, 123839.

Watts, R.L. (1978). Systematic 'abnormal' returns after quarterly earnings announcements. Journal of Financial Economics 6 (2): 127-150.

Wing, C., Simon, K., \& Bello-Gomez, R. A. (2018). Designing difference in difference studies: best practices for public health policy research. Annual review of public health, 39.

Xiao, D., Li, B. \& Cheng, S. (2020). The effect of subway development on air pollution: Evidence from China. Journal of Cleaner Production, 275, 124149.

Yang, Y., Deng, W., Zhang, Y., \& Mao, Z. (2021). Promoting Public Engagement during the 
COVID-19 Crisis: How Effective Is the Wuhan Local Government's Information Release?. International journal of environmental research and public health, 18(1), 118.

Yang, J., Li, Y., Calic, G., \& Shevchenko, A. (2020). How multimedia shape crowdfunding outcomes: The overshadowing effect of images and videos on text in campaign information. Journal of Business Research, 117, 6-18.

Yang, M., Ramiah, V., Moosa, I. \& He, Y., (2018). Narcissism, political tenure, financial indicators and the effectiveness of environmental regulation. Applied Economics 50(21), $2325-2338$.

Zeng, J., Wen, Y., Bi, C. \& Feiock, R. (2021). Effect of tourism development on urban air pollution in China: The moderating role of tourism infrastructure. Journal of Cleaner Production, 280(1), 124397.

Zhang, D., Hu, M., \& Ji, Q. (2020). Financial markets under the global pandemic of COVID19. Finance Research Letters, 36, 101528. 10.1016/j.frl.2020.101528

Zhang, P., Meng, A.X. (2013). The market application analysis of CAPM model in China's securities. Applied Mechanics and Materials, 380-384, 4422-4425. 
Figure 1. Number of Patients Diagnosed in China

Source: The Information on Tencent News Released by the National Health Commission and the Regional Health Commission.

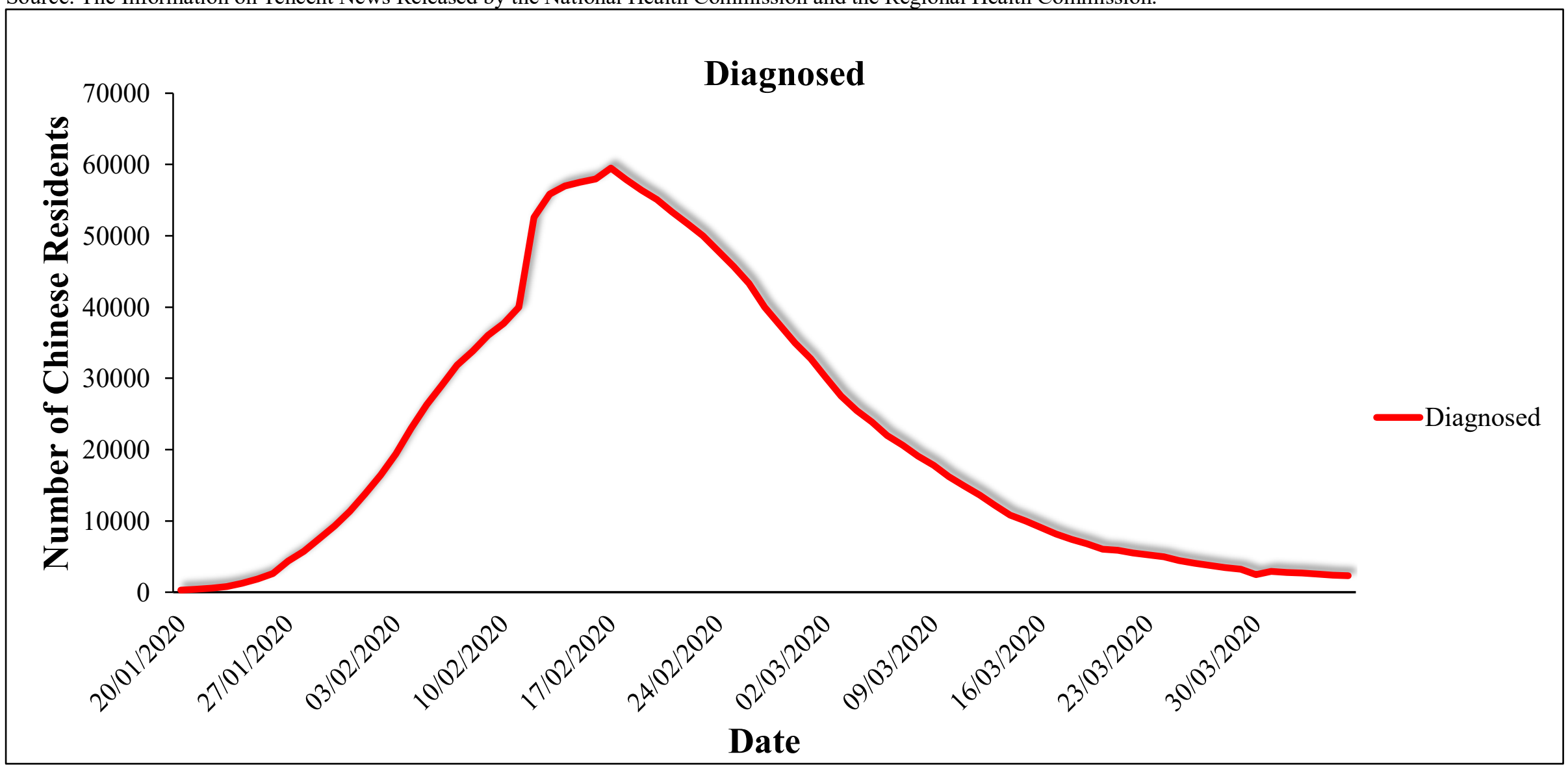

Note: The $\mathrm{X}$-axis represents time and the $\mathrm{Y}$-axis refers to the number of patients diagnosed. 
Figure 2. Number of Suspected Confirmed Cases in China

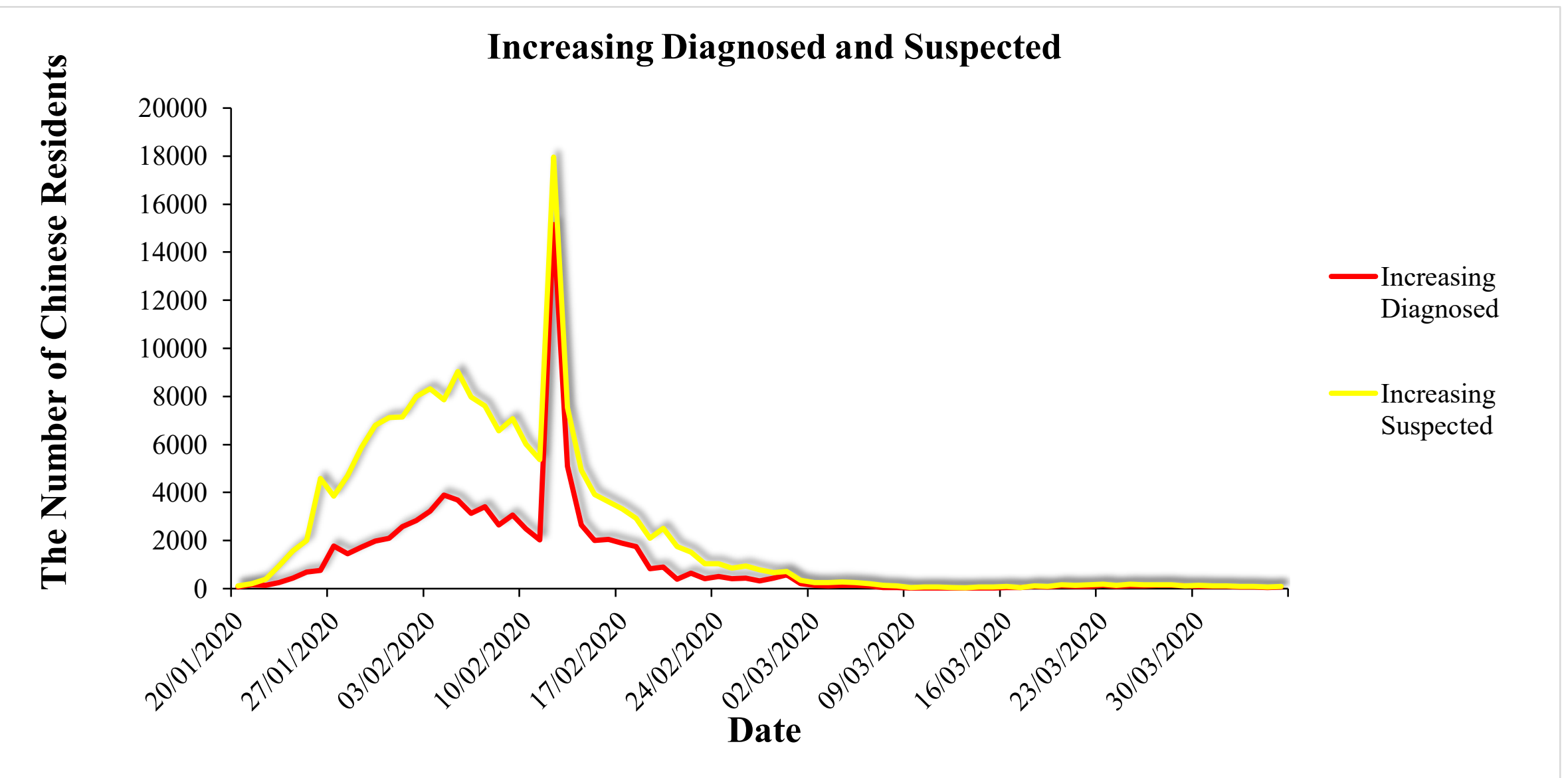

Source: The Information on Tencent News Released by the National Health Commission and the Regional Health Commission.

Note: The X-axis represents time and the Y-axis refers to the number of patients. The red line shows the number of patients diagnosed and the yellow one shows the number of suspected confirmed cases. 
Figure 3. Number of Patients Diagnosed in Hubei

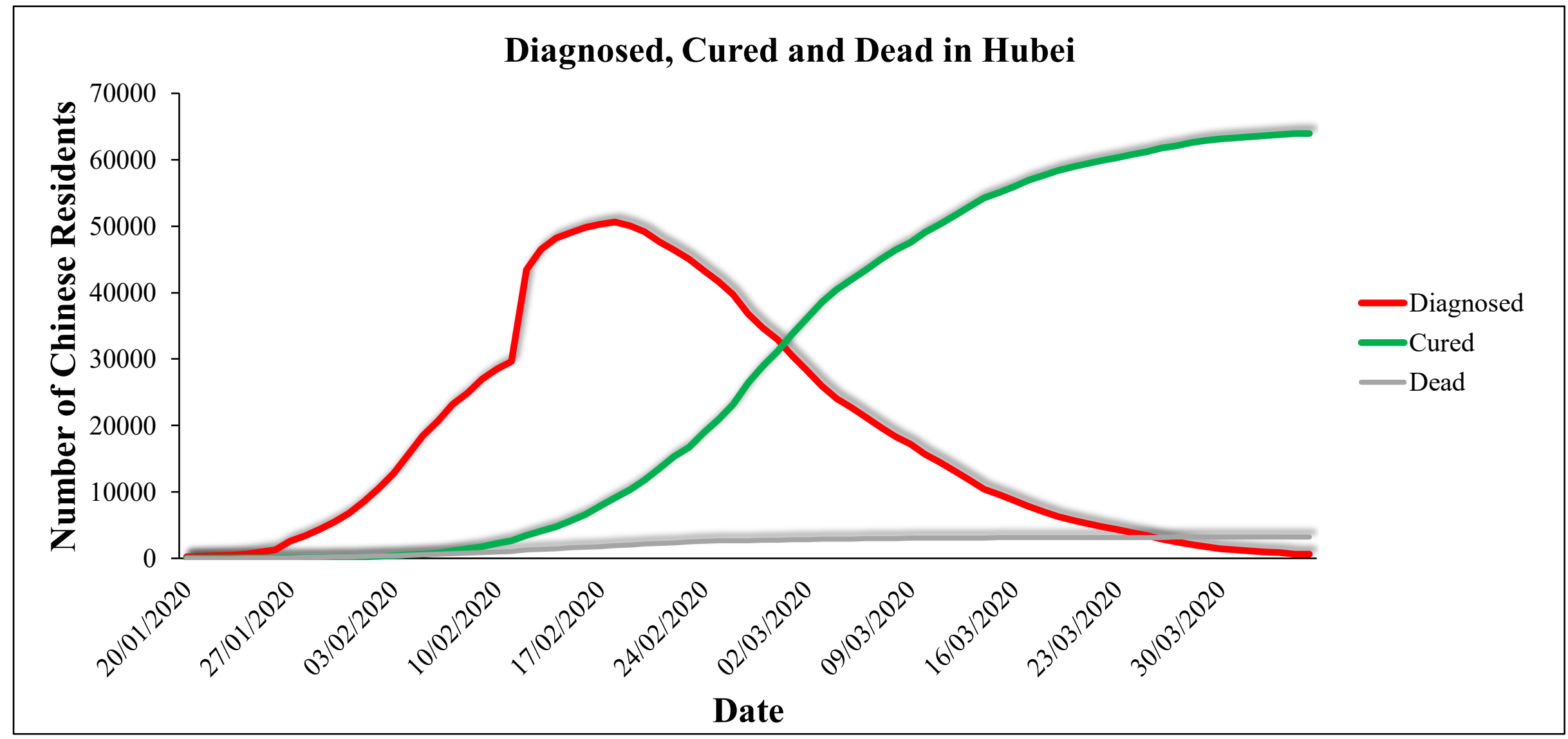

Source: The Information on Tencent News Released by the National Health Commission and the Regional Health Commission.

Note: The X-axis represents time and the Y-axis refers to the number of patients in Hubei. The red line shows the number of existing patients diagnosed, the green line shows the number of cured cases and the grey one presents the number of dead patients. The red line starts to drop from the $16^{\text {th }}$ of February 2020. 
Figure 4. Number of Patients Diagnosed in the Other Provinces or Cities

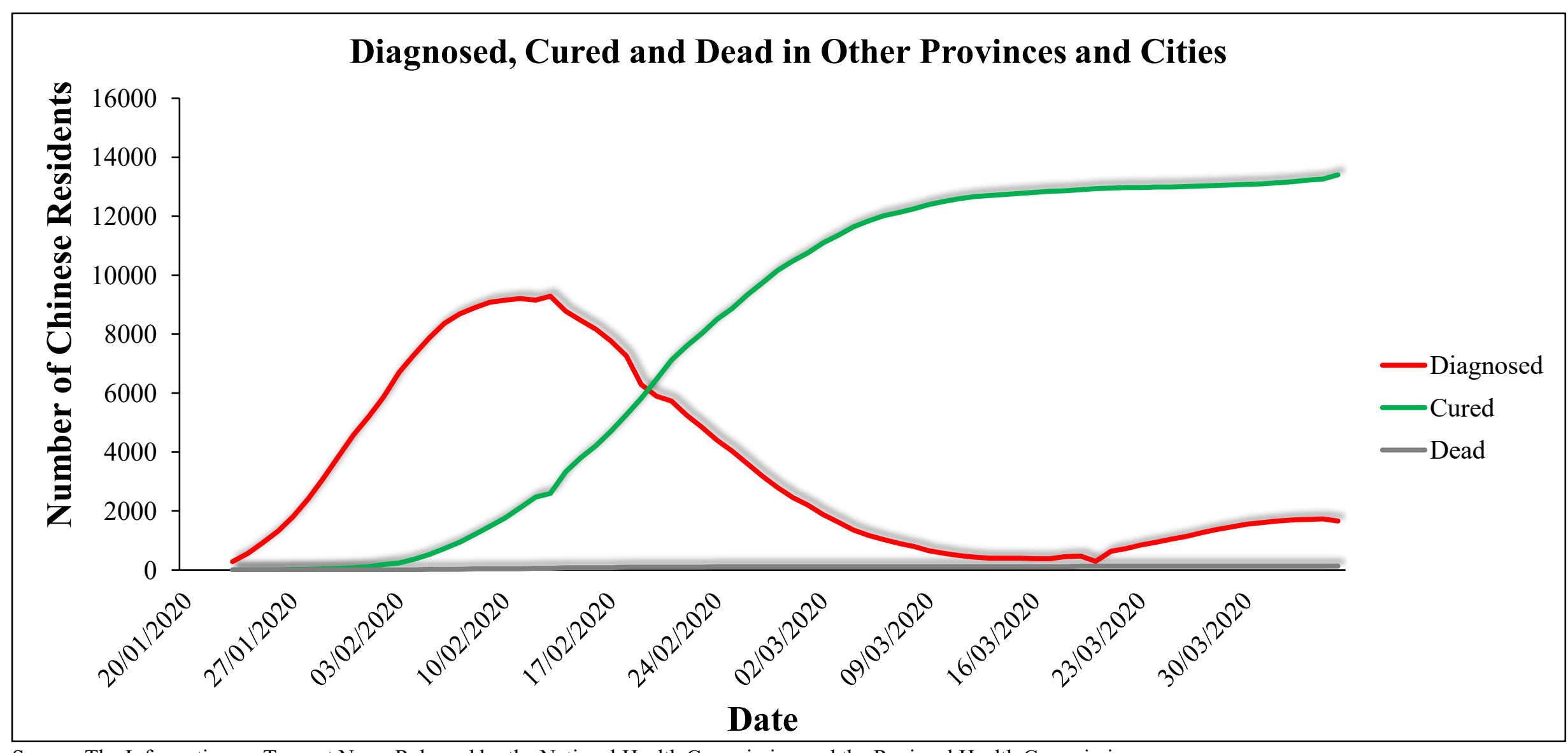

Source: The Information on Tencent News Released by the National Health Commission and the Regional Health Commission.

Note: The X-axis represents time and the Y-axis refers to the number of patients in the other provinces or cities. The red line shows the number of existing patients diagnosed,

the green line shows the number of cured cases and the grey one presents the number of dead patients. The red line starts to drop from the $11^{\text {th }}$ of February 2020 , which is earlier than that in Hubei. 
Figure 5. Number of Users for Online Grocery Shopping

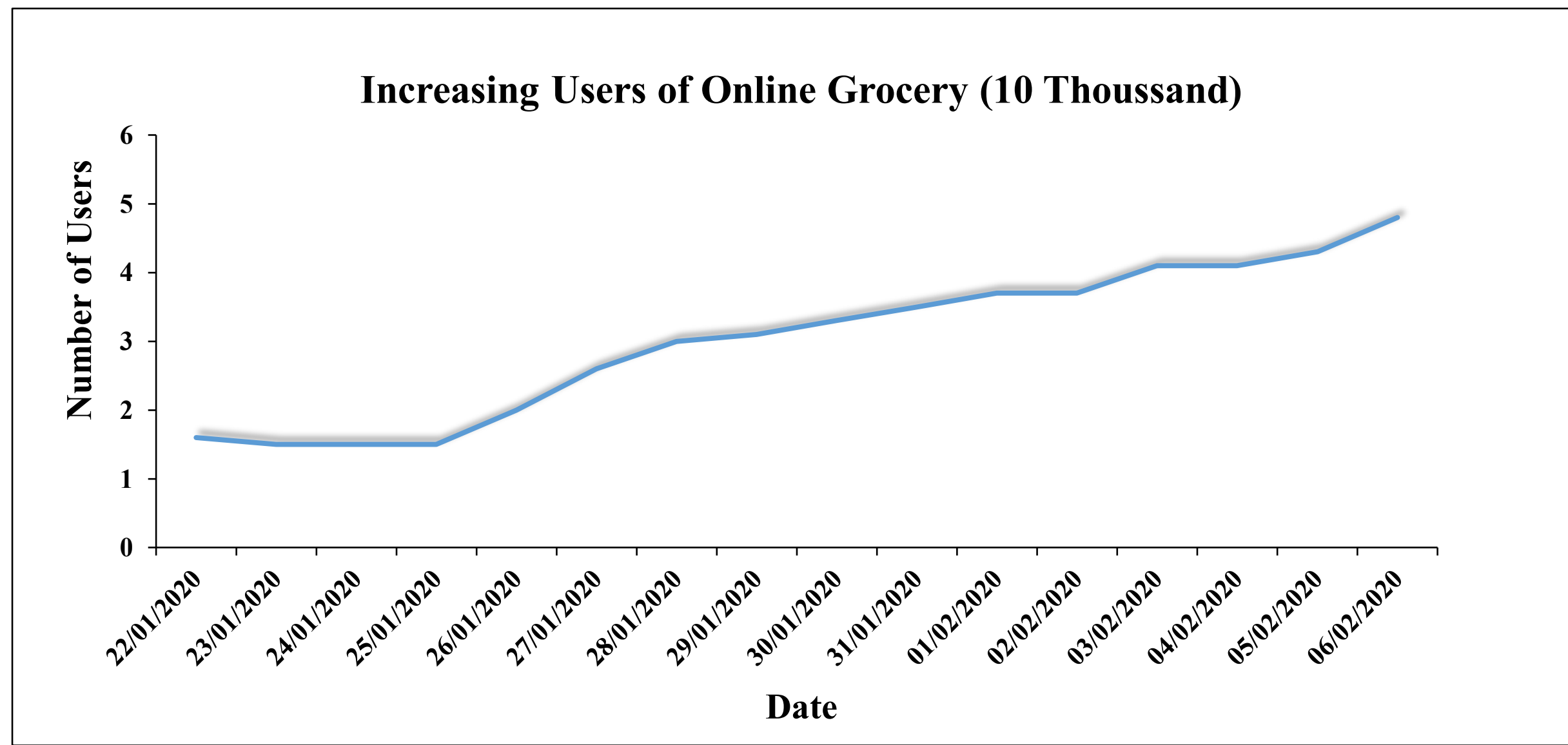

Notes: This figure is drawn based on the information of the usage of an online grocery app, Dingdong Mai Cai, during the Spring Festival holidays in China (on the $22^{\text {nd }}$ of Jan

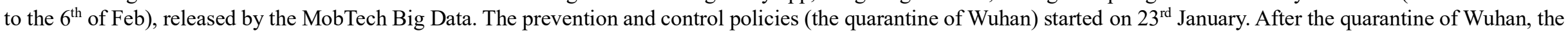
usage of online grocery app increased. 
Figure 6. Number of Users for Online Education Technology

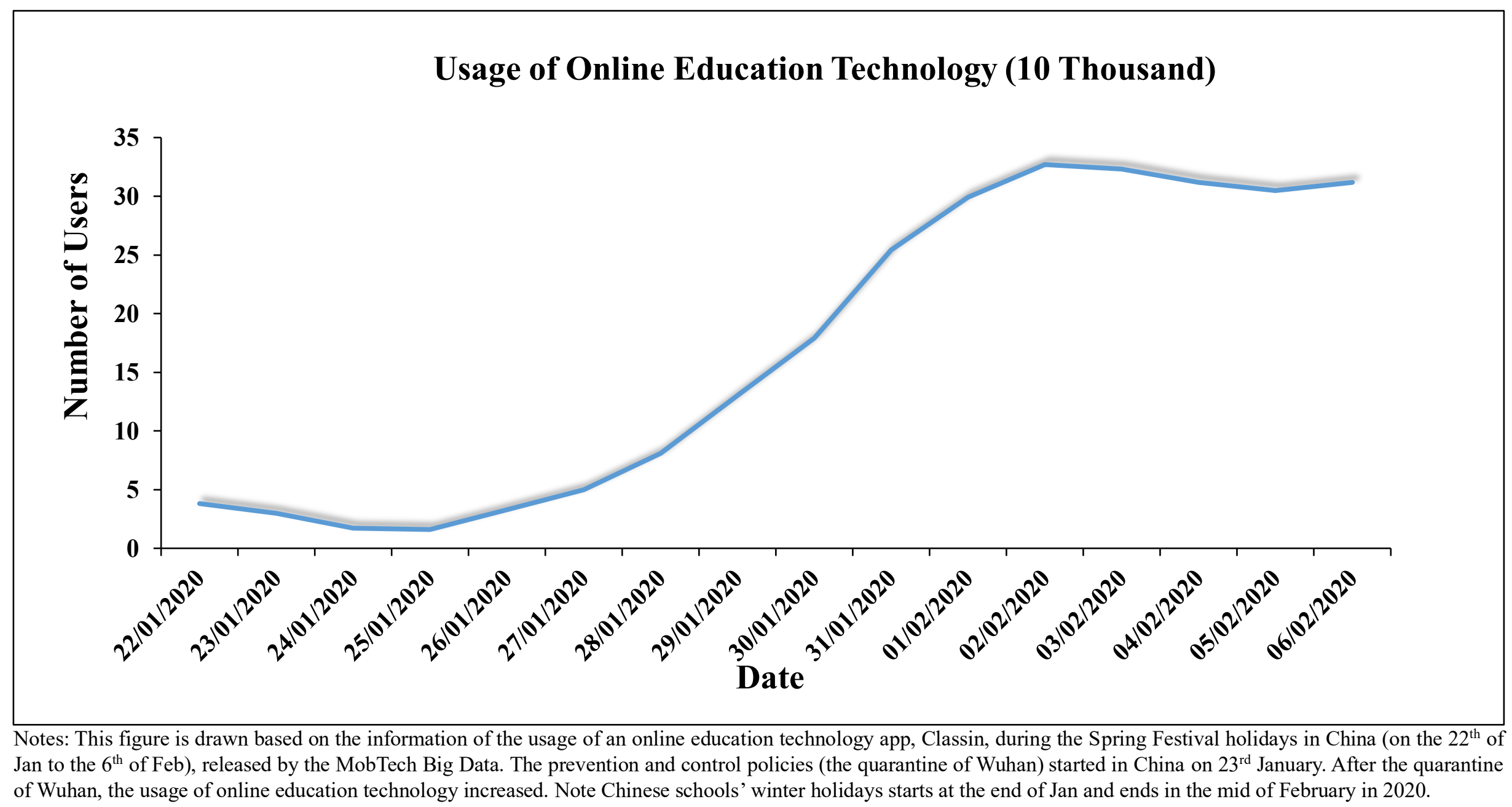




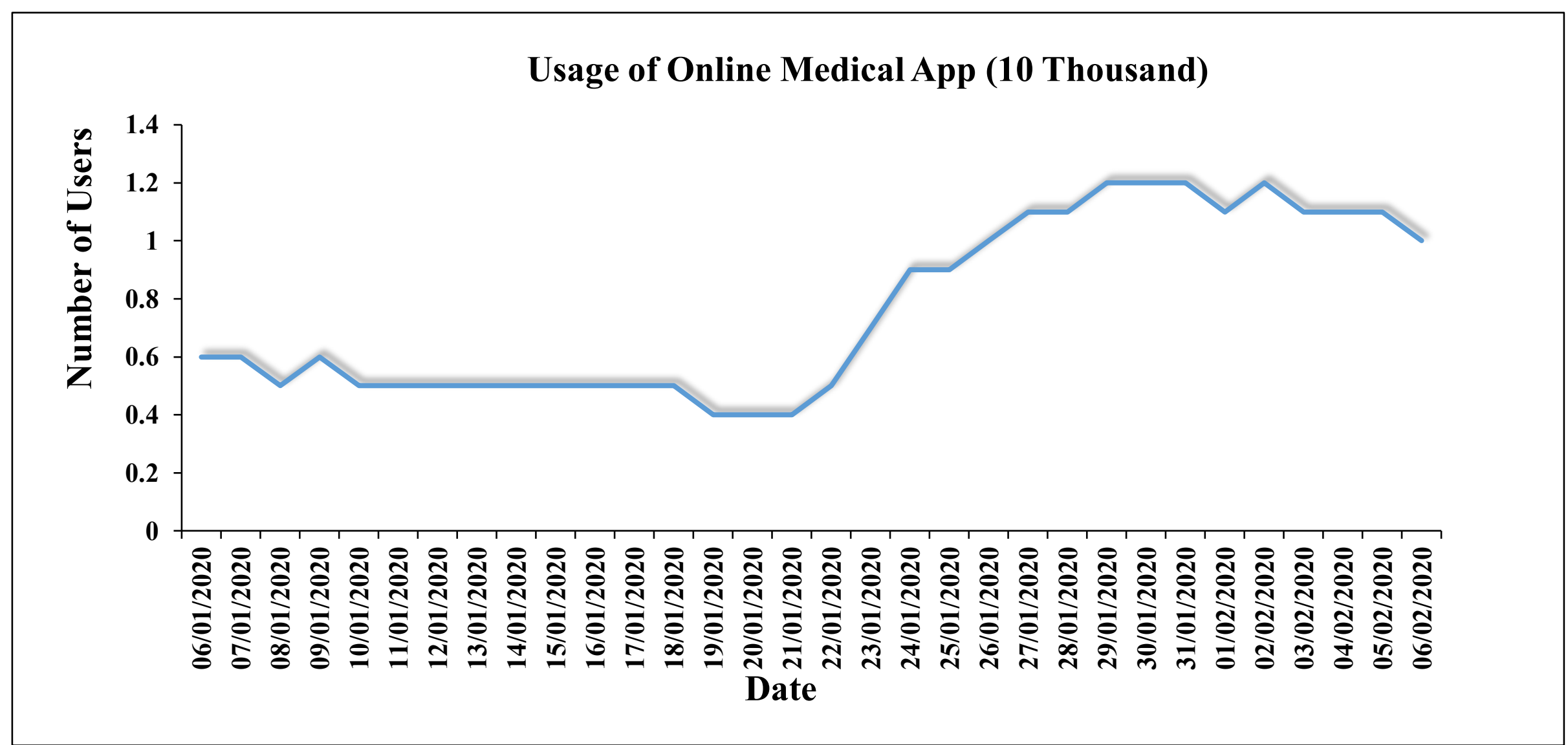

Notes: This figure is drawn based on the information of the usage of an online medical app, Clove Garden, released by the MobTech Big Data. The prevention and control policies (the quarantine of Wuhan) started in China on $23^{\text {rd }}$ January. From the 21 st of January, Clove Garden app released the webpage for real-time tracking of COVID- 19. 


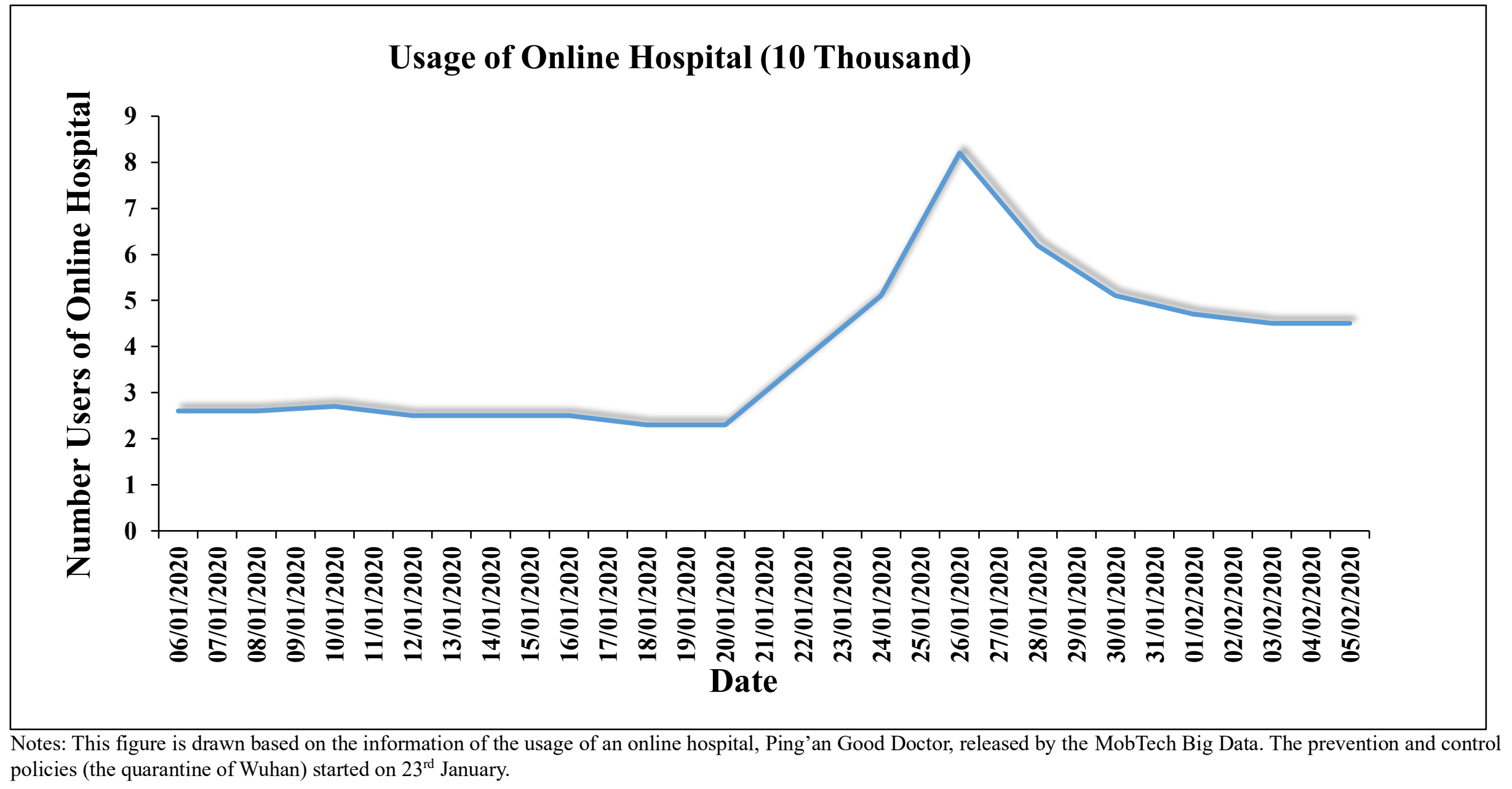




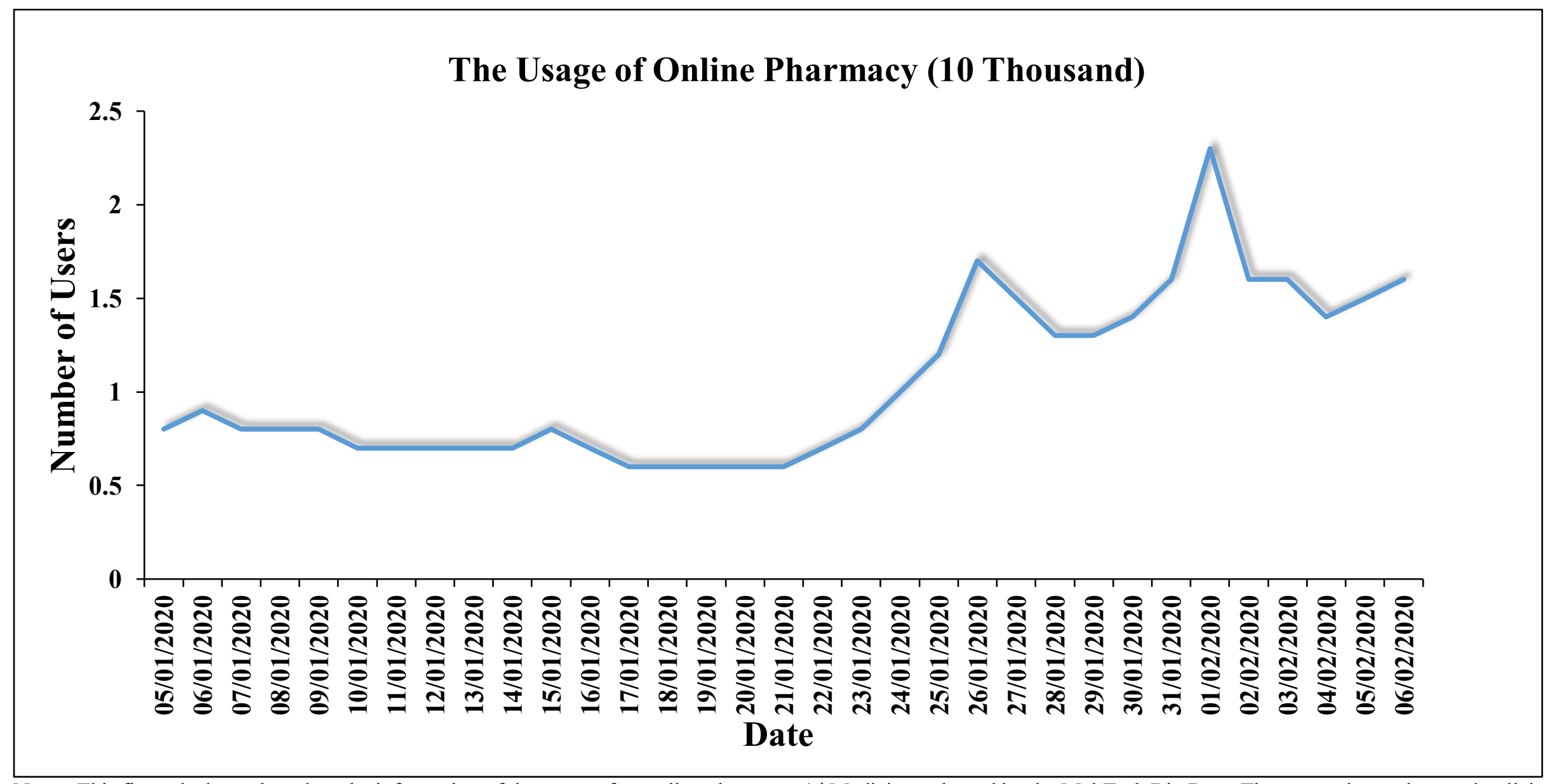

Notes: This figure is drawn based on the information of the usage of an online pharmacy, $1^{\text {st }}$ Medicine, released by the MobTech Big Data. The prevention and control policies (the quarantine of Wuhan) started in China on $23^{\text {rd }}$ January. 
Figure 10. Usage of Online Office App

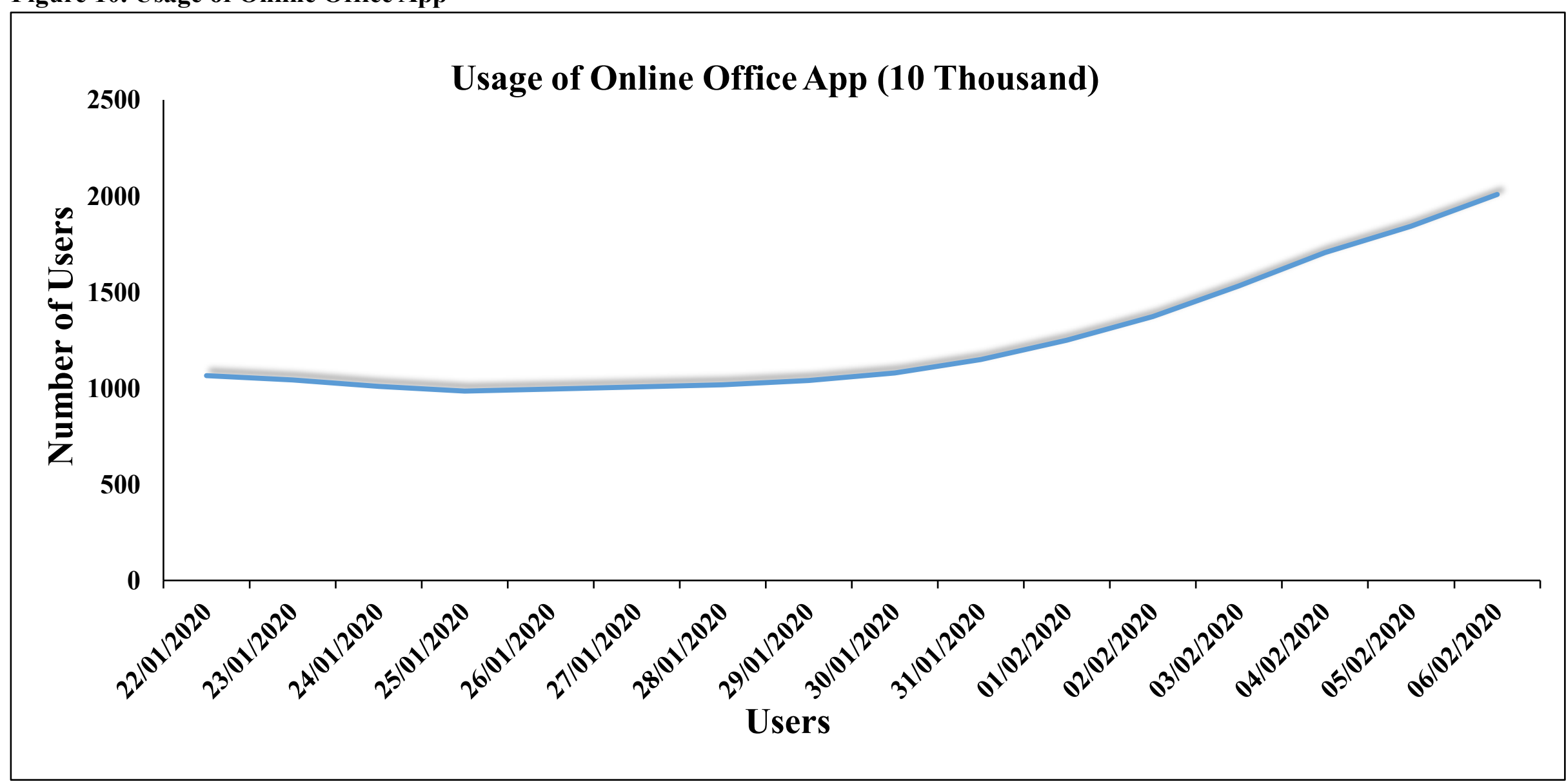

Notes: This figure is drawn based on the information of the usage of an online office, Dingding, released by the MobTech Big Data. The prevention and control policies (the quarantine of Wuhan) started on $23^{\text {rd }}$ January. 
Figure 11. Air Quality Index from June 2019 to May 2020

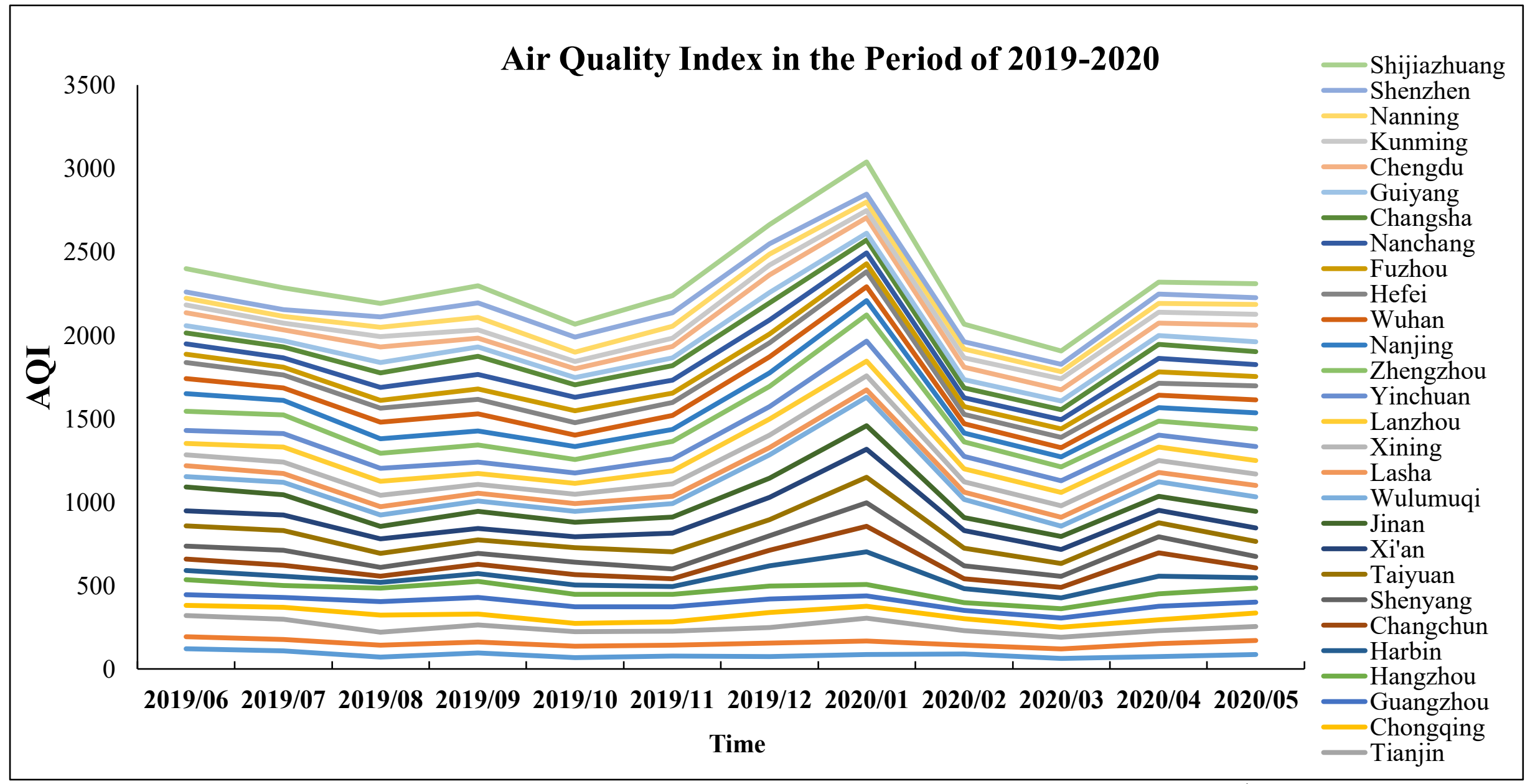

Notes: This figure is drawn based on the information from https://www.aqistudy.cn/historydata/. The quarantine of Wuhan started from the $23^{\text {rd }}$ January. 
Table 1: Summary Statistics and Sample Description

\begin{tabular}{|c|c|c|c|c|c|c|}
\hline \multicolumn{7}{|c|}{ Panel A: Summary Statistics for the Full Sample } \\
\hline Variable & Obs. & Mean & Median & Std. Dev. & Min & Max \\
\hline $\operatorname{CAR}(-1,+1)$ & 5,274 & 0.0002 & -0.0035 & 0.0401 & -0.1759 & 0.2123 \\
\hline $\operatorname{CAR}(-2,+2)$ & 5,274 & 0.0003 & -0.0034 & 0.0507 & -0.2424 & 0.3041 \\
\hline $\operatorname{CAR}(-3,+3)$ & 5,274 & 0.0001 & -0.0038 & 0.0595 & -0.2778 & 0.2968 \\
\hline $\operatorname{CAR}(-5,+5)$ & 5,274 & -0.0007 & -0.0052 & 0.0741 & -0.3246 & 0.5077 \\
\hline $\operatorname{CAR}(0,+1)$ & 5,274 & 0.0006 & -0.0030 & 0.0332 & -0.1517 & 0.1607 \\
\hline $\operatorname{CAR}(0,+2)$ & 5,274 & 0.0011 & -0.0026 & 0.0402 & -0.1694 & 0.2278 \\
\hline $\operatorname{CAR}(0,+3)$ & 5,274 & 0.0008 & -0.0029 & 0.0462 & -0.2081 & 0.2184 \\
\hline $\operatorname{CAR}(0,+5)$ & 5,274 & 0.0004 & -0.0032 & 0.0566 & -0.2985 & 0.3566 \\
\hline Size & 5,274 & 22.7369 & 22.3273 & 1.8456 & 17.8787 & 30.8672 \\
\hline ROA & 5,274 & 0.6861 & 0.0569 & 0.0794 & -1.3455 & 0.6775 \\
\hline DOA & 5,274 & 0.4267 & 0.4094 & 0.2283 & 0.0000 & 2.1463 \\
\hline Fixed Assets & 5,274 & 0.2164 & 0.1882 & 0.1687 & 0.0006 & 0.9542 \\
\hline Intan & 5,274 & 0.0487 & 0.0313 & 0.0754 & 0.0000 & 0.9242 \\
\hline Infe & 5,274 & 0.1 & 0.0000 & 0.3283 & 0.0000 & 1.0000 \\
\hline NTH & 5,274 & 0.1 & 0.0000 & 0.3274 & 0.0000 & 1.0000 \\
\hline BSGCT & 5,274 & 0.3549 & 0.0000 & 0.4785 & 0.0000 & 1.0000 \\
\hline $\mathrm{HB}$ & 5,274 & 0.0264 & 0.0000 & 0.1602 & 0.0000 & 1.0000 \\
\hline \multicolumn{7}{|c|}{ Panel B: Summary Statistics for the Exponential growth sample } \\
\hline Variable & Obs. & Mean & Median & Std. Dev. & Min & Max \\
\hline $\operatorname{CAR}(-1,+1)$ & 1,765 & -0.0010 & -0.0039 & 0.0397 & -0.1759 & 0.1732 \\
\hline $\operatorname{CAR}(-2,+2)$ & 1,765 & -0.0019 & -0.0048 & 0.0512 & -0.2424 & 0.2256 \\
\hline $\operatorname{CAR}(-3,+3)$ & 1,765 & -0.0014 & -0.0052 & 0.0598 & -0.2778 & 0.2904 \\
\hline $\operatorname{CAR}(-5,+5)$ & 1,765 & -0.0012 & -0.0069 & 0.0751 & -0.3246 & 0.5077 \\
\hline $\operatorname{CAR}(0,+1)$ & 1,765 & & -0.0044 & & 517 & 0.1415 \\
\hline $\operatorname{CAR}(0,+2)$ & 1,765 & -0.0015 & -0.0042 & 0.0388 & -0.1514 & 0.2129 \\
\hline $\operatorname{CAR}(0,+3)$ & 1,765 & -0.0019 & -0.0052 & 0.0454 & -0.1811 & 0.1943 \\
\hline $\operatorname{CAR}(0,+5)$ & 1,765 & -0.0013 & -0.0046 & 0.0552 & -0.1903 & 0.2477 \\
\hline $\operatorname{EFF}(-1,1)$ & 1,765 & 0.5365 & 0.5243 & 0.0854 & 0.0000 & 1.0000 \\
\hline $\operatorname{EFF}(-2,2)$ & 1,765 & 0.5252 & 0.5129 & 0.0848 & 0.0000 & 1.0000 \\
\hline $\operatorname{EFF}(-3,3)$ & 1,765 & 0.5292 & 0.5162 & 0.0795 & 0.0000 & 1.0000 \\
\hline $\operatorname{EFF}(-5,5)$ & 1,765 & 0.5207 & 0.5307 & 0.0892 & 0.0000 & 1.0000 \\
\hline Size & 1,765 & 22.7261 & 22.3273 & 1.8544 & 17.8787 & 30.8672 \\
\hline ROA & 1,765 & 0.0676 & 0.0570 & 0.0856 & -1.3455 & 0.6775 \\
\hline DOA & 1,765 & 0.4277 & 0.4050 & 0.2336 & 0.0000 & 2.1463 \\
\hline Fixed Assets & 1,765 & 0.2157 & 0.1882 & 0.1678 & 0.0006 & 0.9542 \\
\hline Intangible & 1,765 & 0.0488 & 0.0314 & 0.0759 & 0.0000 & 0.9242 \\
\hline Infection & 1,765 & 0.1490 & 0.0000 & 0.3562 & 0.0000 & 1.0000 \\
\hline NTH & 1,765 & 0.1269 & 0.0000 & 0.3330 & 0.0000 & 1.0000 \\
\hline BSGCT & 1,765 & 0.3960 & 0.0000 & 0.4892 & 0.0000 & 1.0000 \\
\hline $\mathrm{HB}$ & 1,765 & 0.0317 & 0.0000 & 0.1753 & 0.0000 & 1.0000 \\
\hline
\end{tabular}

Panel C: Summary Statistics for the Flattening the curve sample

\begin{tabular}{lrrrrrr}
\hline Variable & Obs. & Mean & Median & Std. Dev. & Min & Max \\
\hline CAR $(-1,+1)$ & 3,509 & 0.0009 & -0.0031 & 0.0403 & -0.1619 & 0.2123 \\
CAR $(-2,+2)$ & 3,509 & 0.0014 & -0.0026 & 0.0504 & -0.1994 & 0.3041 \\
CAR $(-3,+3)$ & 3,509 & 0.0007 & -0.0031 & 0.0593 & -0.2735 & 0.2968 \\
& & & 40 & & &
\end{tabular}




\begin{tabular}{lrrrrrr} 
CAR $(-5,+5)$ & 3,509 & -0.0004 & -0.0044 & 0.0736 & -0.3160 & 0.3386 \\
CAR $(0,+1)$ & 3,509 & 0.0015 & -0.0021 & 0.0338 & -0.1273 & 0.1607 \\
CAR $(0,+2)$ & 3,509 & 0.0023 & -0.0016 & 0.0407 & -0.1694 & 0.2278 \\
CAR $(0,+3)$ & 3,509 & 0.0021 & -0.0019 & 0.0465 & -0.2081 & 0.2184 \\
CAR $(0,+5)$ & 3,509 & 0.0013 & -0.0020 & 0.0572 & -0.2985 & 0.3566 \\
EFF $(-1,1)$ & 3,509 & 0.4705 & 0.4739 & 0.0799 & 0.0000 & 1.0000 \\
EFF $(-2,2)$ & 3,509 & 0.4805 & 0.4878 & 0.0696 & 0.0000 & 1.0000 \\
EFF $(-3,3)$ & 3,509 & 0.4771 & 0.4670 & 0.0762 & 0.0000 & 1.0000 \\
EFF(-5,5) & 3,509 & 0.4825 & 0.4689 & 0.0701 & 0.0000 & 1.0000 \\
Size & 3,509 & 22.7423 & 22.3273 & 1.8415 & 17.8787 & 30.8672 \\
ROA & 3,509 & 0.0683 & 0.0568 & 0.0761 & -1.3455 & 0.6775 \\
DOA & 3,509 & 0.4262 & 0.4095 & 0.2256 & 0.0000 & 2.1463 \\
Fixed Assets & 3,509 & 0.2168 & 0.1882 & 0.1691 & 0.0006 & 0.9542 \\
Intangible & 3,509 & 0.0486 & 0.0311 & 0.0751 & 0.0000 & 0.9242 \\
Infection & 3,509 & 0.1097 & 0.0000 & 0.3126 & 0.0000 & 1.0000 \\
NTH & 3,509 & 0.1197 & 0.0000 & 0.3246 & 0.0000 & 1.0000 \\
BSGCT & 3,509 & 0.3343 & 0.0000 & 0.4718 & 0.0000 & 1.0000 \\
HB & 3,509 & 0.0237 & 0.0000 & 0.1520 & 0.0000 & 1.0000 \\
\hline
\end{tabular}


Table 2: Test of Difference in Mean of CAR for All Samples

\begin{tabular}{|c|c|c|c|c|c|c|}
\hline \multicolumn{2}{|c|}{ Panel A: Full Sample } & \multirow{2}{*}{$\begin{array}{c}\text { COVID-Minus } \\
\text { Mean }\end{array}$} & \multicolumn{2}{|c|}{ COVID-Plus } & \multicolumn{2}{|c|}{ Test of Difference } \\
\hline Variables & Obs. & & Obs. & Mean & Diff. & t-stat \\
\hline $\operatorname{CAR}(-1,+1)$ & 4,626 & 0.0004 & 648 & -0.0010 & 0.0014 & 0.86 \\
\hline $\operatorname{CAR}(-2,+2)$ & 4,626 & 0.0008 & 648 & -0.0031 & $0.0032 *$ & 1.84 \\
\hline $\operatorname{CAR}(-3,+3)$ & 4,626 & 0.0006 & 648 & -0.0044 & $0.0050 * *$ & 2.00 \\
\hline $\operatorname{CAR}(-5,+5)$ & 4,626 & -0.0001 & 648 & -0.0051 & 0.0050 & 1.63 \\
\hline $\operatorname{CAR}(0,+1)$ & 4,626 & 0.0007 & 648 & -0.0001 & 0.0008 & 0.60 \\
\hline $\operatorname{CAR}(0,+2)$ & 4,626 & 0.0012 & 648 & -0.0001 & 0.0013 & 0.72 \\
\hline $\operatorname{CAR}(0,+3)$ & 4,626 & 0.0008 & 648 & 0.0006 & 0.0002 & 0.09 \\
\hline CAR $(0,+5)$ & 4,626 & 0.0004 & 648 & 0.0008 & -0.0004 & -0.17 \\
\hline \multicolumn{2}{|c|}{ Panel B: Growth } & COVID-Minus & \multicolumn{2}{|c|}{ COVID-Plus } & \multicolumn{2}{|c|}{ Test of Difference } \\
\hline Variables & Obs. & Mean & Obs. & Mean & Diff. & t-stat \\
\hline $\operatorname{CAR}(-1,+1)$ & 1,502 & -0.0006 & 263 & -0.0036 & 0.0030 & 1.14 \\
\hline $\operatorname{CAR}(-2,+2)$ & 1,502 & -0.0008 & 263 & -0.0082 & $0.0074 * *$ & 2.16 \\
\hline $\operatorname{CAR}(-3,+3)$ & 1,502 & -0.0001 & 263 & -0.0095 & $0.0094 * *$ & 2.37 \\
\hline $\operatorname{CAR}(-5,+5)$ & 1,502 & 0.0002 & 263 & -0.0089 & $0.0091 *$ & 1.81 \\
\hline $\operatorname{CAR}(0,+1)$ & 1,502 & -0.0011 & 263 & -0.0025 & 0.0014 & 0.68 \\
\hline $\operatorname{CAR}(0,+2)$ & 1,502 & -0.0011 & 263 & -0.0035 & 0.0024 & 0.92 \\
\hline $\operatorname{CAR}(0,+3)$ & 1,502 & -0.0015 & 263 & -0.0041 & 0.0026 & 0.87 \\
\hline $\operatorname{CAR}(0,+5)$ & 1,502 & -0.0015 & 263 & -0.0004 & -0.0010 & -0.28 \\
\hline $\operatorname{EFF}(-1,1)$ & 1,502 & 0.5533 & 263 & 0.4411 & $0.1122 * * *$ & 22.23 \\
\hline $\operatorname{EFF}(-2,2)$ & 1,502 & 0.5433 & 263 & 0.4221 & $0.1212 * * *$ & 24.84 \\
\hline $\operatorname{EFF}(-3,3)$ & 1,502 & 0.5426 & 263 & 0.4525 & $0.0901 * * *$ & 18.53 \\
\hline $\operatorname{EFF}(-5,5)$ & 1,502 & & 263 & 0.4183 & $0.1204 * * *$ & 23.03 \\
\hline \multicolumn{2}{|c|}{ Panel C: Flattening } & COVID-Minus & \multicolumn{2}{|c|}{ COVID-Plus } & \multicolumn{2}{|c|}{ Test of Difference } \\
\hline Variables & Obs. & Mean & Obs. & Mean & Diff. & t-stat \\
\hline $\operatorname{CAR}(-1,+1)$ & 3,124 & 0.0009 & 385 & 0.0007 & 0.0002 & 0.07 \\
\hline $\operatorname{CAR}(-2,+2)$ & 3,124 & 0.0016 & 385 & 0.0004 & 0.0012 & 0.44 \\
\hline $\operatorname{CAR}(-3,+3)$ & 3,124 & 0.0009 & 385 & -0.0009 & 0.0018 & 0.56 \\
\hline $\operatorname{CAR}(-5,+5)$ & 3,124 & -0.0001 & 385 & -0.0024 & 0.0023 & 0.59 \\
\hline $\operatorname{CAR}(0,+1)$ & 3,124 & 0.0015 & 385 & 0.0014 & 0.0001 & 0.04 \\
\hline $\operatorname{CAR}(0,+2)$ & 3,124 & 0.0023 & 385 & 0.0024 & -0.0001 & -0.03 \\
\hline $\operatorname{CAR}(0,+3)$ & 3,124 & 0.0019 & 385 & 0.0039 & -0.0020 & -0.79 \\
\hline $\operatorname{CAR}(0,+5)$ & 3,124 & 0.0013 & 385 & 0.0016 & -0.0003 & -0.11 \\
\hline $\operatorname{EFF}(-1,1)$ & 3,124 & 0.4622 & 385 & 0.5377 & $-0.0754 * * *$ & -18.29 \\
\hline $\operatorname{EFF}(-2,2)$ & 3,124 & 0.4744 & 385 & 0.5299 & $-0.0555 * * *$ & -15.23 \\
\hline $\operatorname{EFF}(-3,3)$ & 3,124 & 0.4709 & 385 & 0.5273 & $-0.0564 * * *$ & -14.08 \\
\hline $\operatorname{EFF}(-5,5)$ & 3,124 & 0.4760 & 385 & 0.5351 & $-0.0591 * * *$ & -16.16 \\
\hline
\end{tabular}

$* * *, * *$ and $*$ indicate the significance at $1 \%, 5 \%$ and $10 \%$ level. 
Table 3: Average CAR by Events

\begin{tabular}{|c|c|c|c|c|c|c|c|c|}
\hline Event & $\operatorname{CAR}(-1,+1)$ & $\operatorname{CAR}(-2,+2)$ & CAR $(-3,+3)$ & $\operatorname{CAR}(-5,+5)$ & CAR $(0,+1)$ & CAR $(0,+2)$ & CAR $(0,+3)$ & CAR $(0,+5)$ \\
\hline \multirow[t]{2}{*}{1} & $-0.0036 * * *$ & $-0.0050 * * *$ & $-0.0037^{*}$ & -0.0029 & $-0.0048 * * *$ & $-0.0050 * * *$ & $-0.0050^{* * * *}$ & $-0.0039 * *$ \\
\hline & $(-2.67)$ & $(-2.81)$ & $(-1.79)$ & $(-1.11)$ & $(-4.65)$ & $(-3.95)$ & $(-3.35)$ & $(-2.13)$ \\
\hline \multirow[t]{2}{*}{2} & 0.0016 & 0.0013 & 0.0009 & 0.0006 & $0.0023 * *$ & 0.0021 & 0.0012 & 0.0014 \\
\hline & $(1.17)$ & $(0.7540)$ & $(0.46)$ & $(0.23)$ & $(2.07)$ & $(1.59)$ & $(0.78)$ & $(0.72)$ \\
\hline \multirow[t]{2}{*}{3} & 0.0018 & 0.0010 & 0.0001 & -0.0031 & $0.0024 * *$ & $0.0026^{*}$ & $0.0028^{*}$ & 0.0014 \\
\hline & $(1.23)$ & $(0.54)$ & $(0.03)$ & $(-1.21)$ & $(2.00)$ & $(1.82)$ & $(1.71)$ & $(0.71)$ \\
\hline \multirow[t]{2}{*}{4} & $0.0036^{* * *}$ & $0.0051^{* * *}$ & $0.0058 * * *$ & $0.0047^{*}$ & $0.0041 * * *$ & $0.0046^{* * *}$ & $0.0054^{* * *}$ & $0.0053 * * *$ \\
\hline & $(2.69)$ & $(3.05)$ & $(2.98)$ & $(1.92)$ & $(3.68)$ & $(3.47)$ & (3.54) & $(2.73)$ \\
\hline \multirow[t]{2}{*}{5} & $-0.0024^{*}$ & -0.0022 & -0.0030 & -0.0030 & -0.0010 & -0.0003 & -0.0007 & -0.0014 \\
\hline & $(-1.69)$ & $(-1.25)$ & $(-1.39)$ & $(-1.14)$ & $(-0.79)$ & $(-0.21)$ & $(-0.39)$ & $(-0.68)$ \\
\hline \multirow[t]{2}{*}{6} & 0.0005 & 0.0019 & 0.0001 & -0.0002 & 0.0005 & $0.0024^{*}$ & 0.0009 & -0.0002 \\
\hline & $(0.42)$ & $(1.16)$ & $(0.04)$ & $(-0.10)$ & $(0.43)$ & $(1.82)$ & $(0.63)$ & $(-0.13)$ \\
\hline
\end{tabular}

$* * *, * *$ and $*$ indicate the significance at $1 \%, 5 \%$ and $10 \%$ level. T-statistics are in the parentheses. 
Table 4. Average CAR by Sectors

\begin{tabular}{|c|c|c|c|c|c|c|c|c|}
\hline \multicolumn{9}{|c|}{ Panel A: Average CAR for the Full Sample } \\
\hline Sectors & CAR $(-1,+1)$ & CAR $(-2,+2)$ & CAR $(-3,+3)$ & CAR $(-5,+5)$ & $\operatorname{CAR}(0,+1)$ & CAR $(0,+2)$ & CAR $(0,+3)$ & CAR $(0,+5)$ \\
\hline \multicolumn{9}{|l|}{ COVID-Minus } \\
\hline \multirow[t]{2}{*}{ Agriculture } & -0.0062 & -0.0028 & -0.0010 & 0.0051 & -0.0036 & -0.0010 & -0.0008 & 0.0009 \\
\hline & $(-1.21)$ & $(-0.45)$ & $(-0.13)$ & $(0.48)$ & $(-0.97)$ & $(-0.23)$ & $(-0.13)$ & $(0.13)$ \\
\hline \multirow[t]{2}{*}{ Construction } & $0.0064 *$ & 0.0059 & $0.0090 *$ & 0.0027 & $0.0049 *$ & $0.0054 *$ & 0.0040 & 0.0032 \\
\hline & $(1.72)$ & $(1.52)$ & $(1.84)$ & $(0.44)$ & $(1.71)$ & $(1.78)$ & $(1.04)$ & $(0.67)$ \\
\hline \multirow[t]{2}{*}{ Culture } & -0.0015 & 0.0029 & 0.0095 & 0.0064 & -0.0007 & 0.0028 & 0.0064 & 0.0012 \\
\hline & $(-0.31)$ & $(0.50)$ & $(1.58)$ & $(0.82)$ & $(-0.18)$ & $(0.61)$ & $(1.24)$ & $(0.20)$ \\
\hline \multirow[t]{2}{*}{ Education } & $-0.0132 * *$ & $-0.0256 * *$ & $-0.0419 * * *$ & -0.0213 & -0.0101 & $-0.0134^{*}$ & $-0.0194^{*}$ & -0.0153 \\
\hline & $(-2.03)$ & $(-2.46)$ & $(-2.80)$ & $(-1.51)$ & $(-1.42)$ & $(-1.87)$ & $(-1.83)$ & $(-1.61)$ \\
\hline \multirow[t]{2}{*}{ Hotel } & 0.0029 & -0.0022 & 0.0041 & -0.0095 & -0.0050 & $-0.0142 *$ & $-0.0133^{*}$ & $-0.0219 * *$ \\
\hline & $(0.35)$ & $(-0.21)$ & $(0.34)$ & $(-0.77)$ & $(-0.96)$ & $(-1.72)$ & $(-1.68)$ & $(-2.23)$ \\
\hline \multirow[t]{2}{*}{ Leasing } & 0.0001 & -0.0016 & -0.0033 & -0.0037 & -0.0017 & -0.0023 & -0.0016 & -0.0014 \\
\hline & $(0.02)$ & $(-0.28)$ & $(-0.53)$ & $(-0.50)$ & $(-0.47)$ & $(-0.55)$ & $(-0.32)$ & $(-0.22)$ \\
\hline \multirow[t]{2}{*}{ Manufacturing } & 0.0011 & 0.0013 & 0.0008 & 0.0003 & $0.0014 * *$ & $0.0016^{* *}$ & 0.0012 & 0.0007 \\
\hline & $(1.55)$ & $(1.41)$ & $(0.80)$ & $(0.25)$ & (2.33) & $(2.33)$ & $(1.43)$ & $(0.68)$ \\
\hline \multirow[t]{2}{*}{ Materials } & $-0.0051^{*}$ & -0.0043 & -0.0054 & -0.0005 & $-0.0047^{*}$ & -0.0017 & -0.0027 & 0.0003 \\
\hline & $(-1.68)$ & $(-0.99)$ & $(-1.01)$ & $(-0.07)$ & $(-1.90)$ & $(-0.48)$ & $(-0.67)$ & $(0.06)$ \\
\hline \multirow[t]{2}{*}{ Real Estate } & -0.0036 & 0.0003 & -0.0014 & $-0.0093^{*}$ & $-0.0040 *$ & -0.0004 & -0.0030 & $-0.0070 *$ \\
\hline & $(-1.33)$ & $(0.08)$ & $(-0.33)$ & $(-1.79)$ & $(-1.77)$ & $(-0.13)$ & $(-0.93)$ & $(-1.71)$ \\
\hline \multirow[t]{2}{*}{ Research } & 0.0040 & -0.0004 & 0.0025 & 0.0100 & 0.0034 & -0.0007 & 0.0009 & 0.0062 \\
\hline & $(0.74)$ & $(-0.07)$ & $(0.32)$ & $(0.99)$ & $(0.71)$ & $(-0.13)$ & $(0.15)$ & $(0.81)$ \\
\hline \multirow[t]{2}{*}{ Retailing } & $-0.0042 *$ & -0.0047 & -0.0046 & $-0.0098 * *$ & -0.0022 & -0.0018 & -0.0025 & $-0.0057^{*}$ \\
\hline & $(-1.65)$ & $(-1.43)$ & $(-1.14)$ & $(-1.97)$ & $(-1.07)$ & $(-0.74)$ & $(-0.87)$ & $(-1.68)$ \\
\hline \multirow[t]{2}{*}{ Synthesis } & -0.0013 & 0.0011 & -0.0119 & -0.0071 & 0.0051 & 0.0027 & -0.0051 & 0.0027 \\
\hline & $(-0.22)$ & $(0.15)$ & $(-1.28)$ & $(-0.41)$ & $(0.92)$ & $(0.40)$ & $(-0.58)$ & $(0.21)$ \\
\hline \multirow[t]{2}{*}{ Transportation } & -0.0004 & 0.0025 & 0.0024 & 0.0043 & -0.0008 & 0.0008 & 0.0029 & 0.0032 \\
\hline & $(-0.11)$ & $(0.60)$ & $(0.48)$ & $(0.67)$ & $(-0.32)$ & $(0.25)$ & $(0.83)$ & $(0.76)$ \\
\hline
\end{tabular}




\begin{tabular}{|c|c|c|c|c|c|c|c|c|}
\hline Utilities & $\begin{array}{r}-0.0015 \\
(-0.50)\end{array}$ & $\begin{array}{r}-0.0052 \\
(-1.37)\end{array}$ & $\begin{array}{r}-0.0105^{* *} \\
(-2.38)\end{array}$ & $\begin{array}{r}-0.0113 * * \\
(-2.41)\end{array}$ & $\begin{array}{r}-0.0023 \\
(-0.92)\end{array}$ & $\begin{array}{r}-0.0027 \\
(-0.86)\end{array}$ & $\begin{array}{r}-0.0051 \\
(-1.39)\end{array}$ & $\begin{array}{r}-0.0075^{*} \\
(-1.89)\end{array}$ \\
\hline \multicolumn{9}{|l|}{ COVID-Plus } \\
\hline Finance & $\begin{array}{r}0.0010 \\
(0.29)\end{array}$ & $\begin{array}{r}0.0025 \\
(0.61)\end{array}$ & $\begin{array}{r}0.0038 \\
(0.77)\end{array}$ & $\begin{array}{r}0.0086 \\
(1.40)\end{array}$ & $\begin{array}{r}0.0010 \\
(0.34)\end{array}$ & $\begin{array}{r}0.0028 \\
(0.82)\end{array}$ & $\begin{array}{r}0.0038 \\
(0.95)\end{array}$ & $\begin{array}{r}0.0090^{*} \\
(1.75)\end{array}$ \\
\hline Infrastructure & $\begin{array}{r}-0.0083^{*} \\
(-1.75)\end{array}$ & $\begin{array}{r}-0.0121 * * \\
(-2.06)\end{array}$ & $\begin{array}{r}-0.0131 * * \\
(-2.05)\end{array}$ & $\begin{array}{r}-0.0112 \\
(-1.26)\end{array}$ & $\begin{array}{r}-0.0066^{*} \\
(-1.86)\end{array}$ & $\begin{array}{r}-0.0076^{* * *} \\
(-1.96)\end{array}$ & $\begin{array}{r}-0.0055 \\
(-1.32)\end{array}$ & $\begin{array}{r}-0.0023 \\
(-0.38)\end{array}$ \\
\hline IT & $\begin{array}{r}0.0012 \\
(0.56)\end{array}$ & $\begin{array}{r}0.0005 \\
(0.18)\end{array}$ & $\begin{array}{r}0.0007 \\
(0.23)\end{array}$ & $\begin{array}{r}-0.0013 \\
(-0.33)\end{array}$ & $\begin{array}{r}0.0022 \\
(1.21)\end{array}$ & $\begin{array}{r}0.0030 \\
(1.39)\end{array}$ & $\begin{array}{r}0.0047^{*} \\
(1.81)\end{array}$ & $\begin{array}{r}0.0048 \\
(1.54)\end{array}$ \\
\hline Services & $\begin{array}{r}-0.0004 \\
(-0.01)\end{array}$ & $\begin{array}{r}-0.0135 \\
(-0.31)\end{array}$ & $\begin{array}{r}-0.0292 \\
(-0.63)\end{array}$ & $\begin{array}{r}-0.0458 \\
(-1.48)\end{array}$ & $\begin{array}{r}0.0072 \\
(0.24)\end{array}$ & $\begin{array}{r}-0.0036 \\
(-0.08)\end{array}$ & $\begin{array}{r}0.0016 \\
(0.04)\end{array}$ & $\begin{array}{r}-0.0182 \\
(-0.35)\end{array}$ \\
\hline Social Work & $\begin{array}{r}-0.0067 \\
(-0.88) \\
\end{array}$ & $\begin{array}{r}-0.0135 \\
(-1.23) \\
\end{array}$ & $\begin{array}{r}-0.0119 \\
(-1.13) \\
\end{array}$ & $\begin{array}{r}-0.0008 \\
(-0.08) \\
\end{array}$ & $\begin{array}{r}0.0001 \\
(0.01) \\
\end{array}$ & $\begin{array}{r}-0.0022 \\
(-0.25) \\
\end{array}$ & $\begin{array}{r}-0.0025 \\
(-0.29) \\
\end{array}$ & $\begin{array}{r}0.0040 \\
(0.45) \\
\end{array}$ \\
\hline \multicolumn{9}{|c|}{ Panel B: Average CAR for the Exponential Growth Sample } \\
\hline Sectors & CAR $(-1,+1)$ & CAR $(-2,+2)$ & CAR $(-3,+3)$ & CAR $(-5,+5)$ & CAR $(0,+1)$ & CAR $(0,+2)$ & CAR $(0,+3)$ & CAR $(0,+5)$ \\
\hline \multicolumn{9}{|l|}{ COVID-Minus } \\
\hline Agriculture & $\begin{array}{r}-0.0112 \\
(-1.15)\end{array}$ & $\begin{array}{r}-0.0111 \\
(-1.05)\end{array}$ & $\begin{array}{r}-0.0131 \\
(-1.09)\end{array}$ & $\begin{array}{r}-0.0187 \\
(-0.97)\end{array}$ & $\begin{array}{r}-0.0156 * * * \\
(-3.16)\end{array}$ & $\begin{array}{r}-0.0187 * * * \\
(-3.55)\end{array}$ & $\begin{array}{r}-0.0236 * * * \\
(-4.10)\end{array}$ & $\begin{array}{r}-0.0239 * * * \\
(-3.14)\end{array}$ \\
\hline Construction & $\begin{array}{r}0.0077 \\
(1.19)\end{array}$ & $\begin{array}{r}0.0045 \\
(0.66)\end{array}$ & $\begin{array}{r}0.0075 \\
(0.97)\end{array}$ & $\begin{array}{r}-0.0016 \\
(-0.17)\end{array}$ & $\begin{array}{r}0.0090^{*} \\
(1.73)\end{array}$ & $\begin{array}{r}0.0058 \\
(1.01)\end{array}$ & $\begin{array}{r}0.0066 \\
(0.97)\end{array}$ & $\begin{array}{r}0.0016 \\
(0.19)\end{array}$ \\
\hline Culture & $\begin{array}{r}0.0089 \\
(1.09)\end{array}$ & $\begin{array}{r}0.0137 \\
(1.47)\end{array}$ & $\begin{array}{r}0.0187 * * \\
(2.03)\end{array}$ & $\begin{array}{r}0.0150 \\
(1.23)\end{array}$ & $\begin{array}{r}0.0002 \\
(0.04)\end{array}$ & $\begin{array}{r}0.0019 \\
(0.24)\end{array}$ & $\begin{array}{r}0.0045 \\
(0.50)\end{array}$ & $\begin{array}{r}0.0061 \\
(0.59)\end{array}$ \\
\hline Education & $\begin{array}{r}-0.0025 \\
(-0.41)\end{array}$ & $\begin{array}{r}-0.0096 \\
(-0.47)\end{array}$ & $\begin{array}{r}-0.0161 \\
(-0.49)\end{array}$ & $\begin{array}{r}0.0003 \\
(0.02)\end{array}$ & $\begin{array}{r}0.0039 \\
(0.61)\end{array}$ & $\begin{array}{r}-0.0019 \\
(-0.12)\end{array}$ & $\begin{array}{r}0.0026 \\
(0.10)\end{array}$ & $\begin{array}{r}-0.0013 \\
(-0.20)\end{array}$ \\
\hline Hotel & $\begin{array}{r}-0.0092 \\
(-0.56)\end{array}$ & $\begin{array}{r}-0.0222 \\
(-0.87)\end{array}$ & $\begin{array}{r}-0.0043 \\
(-0.13)\end{array}$ & $\begin{array}{r}-0.0266 \\
(-0.82)\end{array}$ & $\begin{array}{r}-0.0089 \\
(-0.69)\end{array}$ & $\begin{array}{r}-0.0168 \\
(-0.80)\end{array}$ & $\begin{array}{r}-0.0193 \\
(-0.95)\end{array}$ & $\begin{array}{r}-0.0309 \\
(-1.54)\end{array}$ \\
\hline Leasing & $\begin{array}{r}-0.0054 \\
(-0.80)\end{array}$ & $\begin{array}{r}-0.0123 \\
(-1.48)\end{array}$ & $\begin{array}{r}-0.0099 \\
(-1.09)\end{array}$ & $\begin{array}{r}-0.0096 \\
(-0.96)\end{array}$ & $\begin{array}{r}-0.0061 \\
(-1.22)\end{array}$ & $\begin{array}{r}-0.0088^{*} \\
(-1.66)\end{array}$ & $\begin{array}{r}-0.0065 \\
(-1.07)\end{array}$ & $\begin{array}{r}-0.0047 \\
(-0.58)\end{array}$ \\
\hline Manufacturing & $\begin{array}{r}-0.0001 \\
(-0.10)\end{array}$ & $\begin{array}{r}-0.0004 \\
(-0.27) \\
\end{array}$ & $\begin{array}{r}-0.0005 \\
(-0.28) \\
\end{array}$ & $\begin{array}{r}0.0000 \\
(0.01)\end{array}$ & $\begin{array}{r}-0.0002 \\
(-0.17)\end{array}$ & $\begin{array}{r}-0.0005 \\
(-0.45) \\
\end{array}$ & $\begin{array}{r}-0.0011 \\
(-0.82)\end{array}$ & $\begin{array}{r}-0.0008 \\
(-0.50)\end{array}$ \\
\hline
\end{tabular}




\begin{tabular}{|c|c|c|c|c|c|c|c|c|}
\hline Mineral & $\begin{array}{r}-0.0079 \\
(-1.30)\end{array}$ & $\begin{array}{r}-0.0108 \\
(-1.22)\end{array}$ & $\begin{array}{r}0.0015 \\
(0.13)\end{array}$ & $\begin{array}{r}0.0137 \\
(0.86)\end{array}$ & $\begin{array}{r}-0.0070 \\
(-1.53)\end{array}$ & $\begin{array}{r}-0.0072 \\
(-1.18)\end{array}$ & $\begin{array}{r}-0.0006 \\
(-0.07)\end{array}$ & $\begin{array}{r}0.0106 \\
(0.91)\end{array}$ \\
\hline \multirow[t]{2}{*}{ Real Estate } & $-0.0078^{*}$ & 0.0026 & 0.0044 & -0.0073 & $-0.0073 * *$ & -0.0002 & -0.0023 & -0.0096 \\
\hline & $(-1.76)$ & $(0.37)$ & $(0.56)$ & $(-0.73)$ & $(-2.29)$ & $(-0.05)$ & $(-0.50)$ & $(-1.57)$ \\
\hline \multirow[t]{2}{*}{ Research } & -0.0079 & -0.0119 & -0.0067 & -0.0027 & -0.0063 & -0.0124 & -0.0116 & -0.0089 \\
\hline & $(-0.98)$ & $(-1.04)$ & $(-0.46)$ & $(-0.20)$ & $(-0.82)$ & $(-1.43)$ & $(-0.91)$ & $(-0.68)$ \\
\hline \multirow[t]{2}{*}{ Retailing } & $-0.0089^{*}$ & $-0.0111 *$ & $-0.0167 * *$ & -0.0079 & $-0.0101 * * *$ & -0.0065 & $-0.0126^{* *}$ & $-0.0114 *$ \\
\hline & $(-1.83)$ & $(-1.85)$ & $(-2.06)$ & $(-0.75)$ & $(-2.76)$ & $(-1.49)$ & $(-2.34)$ & $(-1.91)$ \\
\hline \multirow[t]{2}{*}{ Synthesis } & -0.0058 & -0.0038 & $-0.0250^{*}$ & $-0.0452 * * *$ & -0.0058 & -0.0054 & -0.0207 & -0.0226 \\
\hline & $(-0.58)$ & $(-0.32)$ & $(-1.77)$ & $(-2.70)$ & $(-0.64)$ & $(-0.43)$ & $(-1.23)$ & $(-1.10)$ \\
\hline \multirow[t]{2}{*}{ Transportation } & 0.0092 & 0.0072 & 0.0172 & 0.0147 & 0.0003 & 0.0031 & 0.0107 & 0.0035 \\
\hline & $(0.97)$ & $(0.67)$ & $(1.32)$ & $(0.71)$ & $(0.07)$ & $(0.38)$ & $(1.13)$ & $(0.28)$ \\
\hline \multirow[t]{2}{*}{ Utility } & $-0.0112 * *$ & $-0.0215 * * *$ & $-0.0280 * * *$ & $-0.0257 * * *$ & $-0.0083 * *$ & $-0.0144 * * *$ & $-0.0183 * * *$ & $-0.0156^{* *}$ \\
\hline & $(-2.08)$ & $(-3.07)$ & $(-3.29)$ & $(-3.13)$ & $(-2.07)$ & $(-2.72)$ & $(-2.94)$ & $(-2.17)$ \\
\hline \multicolumn{9}{|l|}{ COVID-Plus } \\
\hline \multirow[t]{2}{*}{ Finance } & 0.0088 & 0.0081 & $0.0214 * *$ & $0.0334 * * *$ & 0.0033 & 0.0046 & 0.0081 & 0.0117 \\
\hline & $(1.31)$ & $(1.03)$ & $(2.29)$ & $(3.07)$ & $(0.66)$ & $(0.79)$ & $(1.19)$ & $(1.28)$ \\
\hline \multirow[t]{2}{*}{ Infrastructure } & -0.0106 & -0.0157 & -0.0144 & -0.0159 & $-0.0123 * *$ & $-0.0102 *$ & -0.0076 & -0.0008 \\
\hline & $(-1.21)$ & $(-1.52)$ & $(-1.43)$ & $(-1.05)$ & $(-2.05)$ & $(-1.66)$ & $(-1.26)$ & $(-0.08)$ \\
\hline \multirow[t]{2}{*}{ IT } & 0.0014 & -0.0002 & -0.0012 & -0.0008 & 0.0020 & 0.0026 & 0.0022 & 0.0054 \\
\hline & $(0.51)$ & $(-0.05)$ & $(-0.26)$ & $(-0.14)$ & $(0.88)$ & $(0.90)$ & $(0.57)$ & $(1.22)$ \\
\hline \multirow[t]{2}{*}{ Social Work } & -0.0105 & -0.0249 & -0.0145 & -0.0141 & -0.0031 & -0.0099 & -0.0088 & -0.0037 \\
\hline & $(-1.09)$ & $(-1.55)$ & $(-0.93)$ & $(-1.05)$ & $(-0.30)$ & $(-0.74)$ & $(-0.64)$ & $(-0.30)$ \\
\hline \multicolumn{9}{|c|}{ Panel C: Average CAR for the Flattening the Curve Sample } \\
\hline Sectors & CAR $(-1,+1)$ & $\operatorname{CAR}(-2,+2)$ & CAR $(-3,+3)$ & $\operatorname{CAR}(-5,+5)$ & CAR $(0,+1)$ & CAR $(0,+2)$ & CAR $(0,+3)$ & CAR $(0,+5)$ \\
\hline \multicolumn{9}{|l|}{ COVID-Minus } \\
\hline \multirow[t]{2}{*}{ Agriculture } & -0.0051 & -0.0009 & 0.0017 & 0.0104 & -0.0009 & 0.0030 & 0.0044 & 0.0065 \\
\hline & $(-0.85)$ & $(-0.12)$ & $(0.18)$ & $(0.86)$ & $(-0.20)$ & $(0.62)$ & $(0.66)$ & $(0.78)$ \\
\hline \multirow[t]{2}{*}{ Construction } & 0.0058 & 0.0065 & 0.0097 & 0.0045 & 0.0032 & 0.0052 & 0.0030 & 0.0039 \\
\hline & $(1.29)$ & $(1.37)$ & $(1.56)$ & $(0.59)$ & $(0.93)$ & $(1.46)$ & $(0.63)$ & $(0.66)$ \\
\hline
\end{tabular}




\begin{tabular}{|c|c|c|c|c|c|c|c|c|}
\hline Culture & $\begin{array}{r}-0.0096^{*} \\
(-1.68)\end{array}$ & $\begin{array}{r}-0.0055 \\
(-0.79)\end{array}$ & $\begin{array}{r}0.0024 \\
(0.31)\end{array}$ & $\begin{array}{r}-0.0002 \\
(-0.02)\end{array}$ & $\begin{array}{r}-0.0014 \\
(-0.31)\end{array}$ & $\begin{array}{r}0.0035 \\
(0.64)\end{array}$ & $\begin{array}{r}0.0079 \\
(1.29)\end{array}$ & $\begin{array}{r}-0.0026 \\
(-0.38)\end{array}$ \\
\hline \multirow[t]{2}{*}{ Education } & $-0.0185 * *$ & $-0.0336 * * *$ & $-0.0549 * * *$ & $-0.0322 *$ & $-0.0171 * *$ & $-0.0191 * * *$ & $-0.0305 * * *$ & $-0.0223 *$ \\
\hline & $(-2.21)$ & $(-2.86)$ & $(-3.73)$ & $(-1.85)$ & $(-2.03)$ & $(-2.57)$ & $(-4.35)$ & $(-1.72)$ \\
\hline \multirow[t]{2}{*}{ Hotel } & 0.0086 & 0.0071 & 0.0080 & -0.0016 & -0.0032 & $-0.0130 *$ & -0.0106 & -0.0177 \\
\hline & $(0.88)$ & $(0.73)$ & $(0.80)$ & $(-0.15)$ & $(-0.63)$ & $(-1.66)$ & $(-1.43)$ & $(-1.56)$ \\
\hline \multirow[t]{2}{*}{ Leasing } & 0.0055 & 0.0091 & 0.0032 & 0.0022 & 0.0026 & 0.0042 & 0.0033 & 0.0020 \\
\hline & $(1.02)$ & $(1.22)$ & $(0.36)$ & $(0.20)$ & $(0.49)$ & $(0.65)$ & $(0.43)$ & $(0.22)$ \\
\hline \multirow[t]{2}{*}{ Manufacturing } & 0.0017 & $0.0021^{*}$ & 0.0015 & 0.0005 & $0.0022 * * *$ & $0.0028 * * *$ & $0.0023 * *$ & 0.0014 \\
\hline & $(1.98)$ & $(1.94)$ & $(1.20)$ & $(0.30)$ & $(2.97)$ & $(3.16)$ & $(2.34)$ & (1.18) \\
\hline \multirow[t]{2}{*}{ Mineral } & -0.0042 & -0.0023 & -0.0075 & -0.0048 & -0.0039 & 0.0000 & -0.0034 & -0.0028 \\
\hline & $(-1.20)$ & $(-0.46)$ & $(-1.24)$ & $(-0.65)$ & $(-1.37)$ & $(0.01)$ & $(-0.73)$ & $(-0.48)$ \\
\hline \multirow[t]{2}{*}{ Real Estate } & -0.0012 & -0.0010 & -0.0048 & $-0.0105^{*}$ & -0.0021 & -0.0005 & -0.0033 & -0.0054 \\
\hline & $(-0.36)$ & $(-0.25)$ & $(-0.92)$ & $(-1.77)$ & $(-0.69)$ & $(-0.13)$ & $(-0.78)$ & $(-1.01)$ \\
\hline \multirow[t]{2}{*}{ Research } & 0.0089 & 0.0043 & 0.0063 & 0.0153 & 0.0075 & 0.0042 & 0.0061 & 0.0125 \\
\hline & $(1.31)$ & $(0.56)$ & $(0.68)$ & $(1.17)$ & $(1.26)$ & $(0.66)$ & $(0.88)$ & $(1.35)$ \\
\hline \multirow[t]{2}{*}{ Retailing } & -0.0028 & -0.0028 & -0.0009 & $-0.0104^{*}$ & 0.0001 & -0.0004 & 0.0005 & -0.0040 \\
\hline & $(-0.94)$ & $(-0.72)$ & $(-0.21)$ & $(-1.83)$ & $(0.05)$ & $(-0.15)$ & $(0.16)$ & $(-1.00)$ \\
\hline \multirow[t]{2}{*}{ Synthesis } & 0.0010 & 0.0035 & -0.0053 & 0.0119 & 0.0106 & 0.0067 & 0.0027 & 0.0154 \\
\hline & $(0.15)$ & $(0.39)$ & $(-0.45)$ & $(0.51)$ & $(1.54)$ & $(0.83)$ & $(0.27)$ & $(0.95)$ \\
\hline \multirow[t]{2}{*}{ Transportation } & -0.0019 & 0.0017 & 0.0000 & 0.0026 & -0.0010 & 0.0004 & 0.0017 & 0.0032 \\
\hline & $(-0.51)$ & $(0.39)$ & $(0.01)$ & $(0.39)$ & $(-0.35)$ & $(0.12)$ & $(0.45)$ & $(0.70)$ \\
\hline \multirow[t]{2}{*}{ Utility } & 0.0036 & 0.0033 & -0.0015 & -0.0038 & 0.0009 & 0.0034 & 0.0017 & -0.0033 \\
\hline & $(1.02)$ & $(0.79)$ & $(-0.30)$ & $(-0.68)$ & $(0.30)$ & $(0.90)$ & $(0.38)$ & $(-0.69)$ \\
\hline \multicolumn{9}{|l|}{ COVID-Plus } \\
\hline \multirow[t]{2}{*}{ Finance } & -0.0017 & 0.0006 & -0.0023 & 0.0001 & 0.0001 & 0.0022 & 0.0023 & 0.0081 \\
\hline & $(-0.41)$ & $(0.12)$ & $(-0.40)$ & $(0.01)$ & $(0.04)$ & $(0.52)$ & $(0.47)$ & $(1.30)$ \\
\hline \multirow[t]{2}{*}{ Infrastructure } & -0.0064 & -0.0091 & -0.0119 & -0.0073 & -0.0019 & -0.0054 & -0.0038 & -0.0036 \\
\hline & $(-1.32)$ & $(-1.39)$ & $(-1.45)$ & $(-0.70)$ & $(-0.46)$ & $(-1.09)$ & $(-0.65)$ & $(-0.50)$ \\
\hline IT & 0.0010 & 0.0009 & 0.0021 & -0.0017 & 0.0023 & 0.0033 & $0.0065^{*}$ & 0.0045 \\
\hline
\end{tabular}




\begin{tabular}{cccccrrrr} 
& $(0.33)$ & $(0.25)$ & $(0.49)$ & $(-0.31)$ & $(0.88)$ & $(1.06)$ & $(1.83)$ & $(1.02)$ \\
Services & -0.0004 & -0.0135 & -0.0292 & -0.0458 & 0.0072 & -0.0036 & 0.0016 & -0.0182 \\
& $(-0.01)$ & $(-0.31)$ & $(-0.63)$ & $(-1.48)$ & $(0.24)$ & $(-0.08)$ & $(0.04)$ & $(-0.35)$ \\
Social Work & -0.0021 & 0.0001 & -0.0087 & 0.0149 & 0.0037 & 0.0069 & 0.0049 & 0.0130 \\
& $(-0.17)$ & $(0.01)$ & $(-0.61)$ & $(0.84)$ & $(0.33)$ & $(0.62)$ & $(0.48)$ & $(1.04)$ \\
\hline ***** and * indicate the significance at $1 \%, 5 \%$ and $10 \%$ level T-statistics are in the parentheses. & & &
\end{tabular}


Table 5: Average Effectiveness Scores by Events

\begin{tabular}{crrrr}
\hline Event & EFF (-1,1) & EFF (-2,2) & EFF (-3,3) & EFF (-5,5) \\
\hline $\mathbf{1}$ & $0.5499^{* * *}$ & $0.5376^{* * *}$ & $0.5376^{* * *}$ & $0.5219^{* * *}$ \\
& $(5.33)$ & $(5.68)$ & $(6.18)$ & $(5.37)$ \\
$\mathbf{2}$ & $0.5229^{* * *}$ & $0.5126^{* * *}$ & $0.5206^{* * *}$ & $0.5195^{* * *}$ \\
& $(8.80)$ & $(7.18)$ & $(7.43)$ & $(6.47)$ \\
$\mathbf{3}$ & $0.4766^{* * *}$ & $0.4572^{* * *}$ & $0.4447^{* * *}$ & $0.4629^{* * *}$ \\
& $(6.58)$ & $(6.41)$ & $(5.85)$ & $(5.64)$ \\
$\mathbf{4}$ & $0.4881^{* * *}$ & $0.5096^{* * *}$ & $0.5085^{* * *}$ & $0.5176^{* * *}$ \\
& $(7.16)$ & $(10.00)$ & $(8.42)$ & $(9.64)$ \\
$\mathbf{5}$ & $0.4335^{* * *}$ & $0.4702^{* * *}$ & $0.4748^{* * *}$ & $0.4794 * * *$ \\
& $(5.62)$ & $(6.89)$ & $(5.69)$ & $(8.46)$ \\
$\mathbf{6}$ & $0.4835^{* * *}$ & $0.4846^{* * *}$ & $0.4800^{* * *}$ & $0.4698^{* * *}$ \\
& $(5.45)$ & $(6.51)$ & $(6.90)$ & $(6.59)$ \\
\hline
\end{tabular}

*** indicates the significance at $1 \%$ level. T-statistics are in the parentheses. 
Table 6: Average Effectiveness Scores by Sectors

\begin{tabular}{|c|c|c|c|c|}
\hline \multicolumn{5}{|c|}{ Panel A: Average Effectiveness for the Exponential Growth Sample } \\
\hline Sector & EFF(-1,1) & EFF $(-2,2)$ & EFF $(-3,3)$ & EFF $(-5,5)$ \\
\hline \multicolumn{5}{|l|}{ COVID-Minus } \\
\hline \multirow[t]{2}{*}{ Construction } & $0.4390 * * *$ & $0.5366^{* * *}$ & $0.4878^{* * *}$ & $0.6098 * * *$ \\
\hline & $(11.06)$ & (17.62) & (7.84) & \\
\hline \multirow[t]{2}{*}{ Culture } & $0.4324 * * *$ & $0.4324 * * *$ & $0.3784 * * *$ & $0.4595 * * *$ \\
\hline & (7.23) & (7.23) & (6.49) & (23.64) \\
\hline \multirow[t]{2}{*}{ Education } & 0.5000 & 0.5000 & 0.5000 & 0.5000 \\
\hline & $(0.71)$ & $(0.71)$ & $(0.71)$ & $(0.71)$ \\
\hline \multirow[t]{2}{*}{ Leasing } & $0.5750^{* * *}$ & $0.7000^{* * *}$ & $0.6500^{* * *}$ & $0.6500^{* * *}$ \\
\hline & (216.65) & (10.99) & (6.44) & (122.45) \\
\hline \multirow{2}{*}{ Manufacturing } & $0.5485^{* * *}$ & $0.5405^{* * *}$ & $0.5459^{* * *}$ & $0.5423 * * *$ \\
\hline & $(20.43)$ & (17.71) & (16.62) & $(42.41)$ \\
\hline \multirow[t]{2}{*}{ Mineral } & $0.6452^{* * *}$ & $0.5806^{* * *}$ & $0.5161 * * *$ & $0.4194 * * *$ \\
\hline & (7.48) & $(4.53)$ & $(5.27)$ & $(25.71)$ \\
\hline \multirow[t]{2}{*}{ Research } & $0.4545^{* * *}$ & $0.5455^{* * *}$ & $0.5000^{* * *}$ & $0.5000 * * *$ \\
\hline & (5.56) & (30.03) & $(10.01)$ & $(10.01)$ \\
\hline \multirow[t]{2}{*}{ Retailing } & $0.7091 * * *$ & $0.6364 * * *$ & $0.6182 * * *$ & $0.4909^{* *}$ \\
\hline & $(10.26)$ & $(6.40)$ & $(3.89)$ & $(2.32)$ \\
\hline \multirow{2}{*}{ Transportation } & $0.5789 * * *$ & $0.5263 * * *$ & $0.4737 * * *$ & $0.4211^{* * *}$ \\
\hline & $(14.84)$ & (6.13) & (7.59) & $(2.25)$ \\
\hline \multirow[t]{2}{*}{ Utility } & $0.2679 * *$ & $0.3036^{* * *}$ & $0.3750 * * *$ & $0.3036 * * *$ \\
\hline & $(2.55)$ & (3.24) & (5.28) & (3.24) \\
\hline \multicolumn{5}{|l|}{ COVID-Plus } \\
\hline \multirow[t]{2}{*}{ Finance } & $0.4595 * * *$ & $0.3784 * * *$ & $0.4054 * * *$ & $0.3243 * * *$ \\
\hline & (11.49) & $(5.80)$ & (10.52) & (36.48) \\
\hline \multirow[t]{2}{*}{ Infrastructure } & $0.4737 * * *$ & $0.4474 * * *$ & $0.4211 * * *$ & $0.3947 * * *$ \\
\hline & (8.39) & $(5.20)$ & (49.72) & $(10.36)$ \\
\hline \multirow[t]{2}{*}{ IT } & $0.4936 * * *$ & $0.4679 * * *$ & $0.4872 * * *$ & $0.4679 * * *$ \\
\hline & (11.39) & (15.73) & (8.78) & $(33.00)$ \\
\hline \multirow{2}{*}{ Social Work } & $0.4615^{* * *}$ & $0.3077 * *$ & $0.4615^{* * *}$ & $0.3846^{* * *}$ \\
\hline & (3.74) & $(2.26)$ & (12.45) & (7.78) \\
\hline \multicolumn{5}{|c|}{ Panel B: Average Effectiveness for the Flattening the Curve Sample } \\
\hline Sector & EFF(-1,1) & EFF $(-2,2)$ & EFF $(-3,3)$ & EFF $(-5,5)$ \\
\hline COVID-Minus & & & & \\
\hline Agriculture & $\begin{array}{r}0.3208^{* *} \\
(2.47)\end{array}$ & $\begin{array}{r}0.3396^{* * * *} \\
(4.40)\end{array}$ & $\begin{array}{r}0.3774 * * * \\
(657)\end{array}$ & $\begin{array}{r}0.5094 * * * \\
(1500)\end{array}$ \\
\hline \multirow{2}{*}{ Construction } & $0.5510^{* * *}$ & $\begin{array}{r}(4.40) \\
0.5102 * * * *\end{array}$ & $0.5918^{* * * *}$ & $0.5408 * * *$ \\
\hline & (4.79) & (3.59) & (7.43) & $(12.10)$ \\
\hline \multirow{2}{*}{ Hotel } & $0.5333^{* * *}$ & $0.4000^{*}$ & 0.4667 & $0.6000^{* * *}$ \\
\hline & (4.46) & (1.77) & (1.36) & (2.98) \\
\hline \multirow[t]{2}{*}{ Leasing } & $0.4500^{* * *}$ & $0.4750 * * *$ & $0.4500^{* * *}$ & $0.4250^{* * *}$ \\
\hline & $(4.72)$ & (5.79) & (4.72) & (4.11) \\
\hline Manufacturing & $0.4753^{* * *}$ & $0.4836 * * *$ & $0.4734 * * *$ & $0.4762 * * *$ \\
\hline & $(16.62)$ & (20.71) & $(16.08)$ & (15.24) \\
\hline Mineral & $0.4059 * * *$ & $0.4059 * * *$ & $0.3960^{* * *}$ & $0.4554 * * *$ \\
\hline & (16.13) & (7.16) & (5.98) & $(6.38)$ \\
\hline & & 50 & & \\
\hline
\end{tabular}




\begin{tabular}{crrrr} 
Real Estate & $0.4701 * * *$ & $0.4444 * * *$ & $0.4274 * * *$ & $0.3675 * * *$ \\
& $(5.08)$ & $(6.70)$ & $(15.33)$ & $(10.60)$ \\
Research & $0.4528^{* * *}$ & $0.5283^{* * *}$ & $0.5660^{* * *}$ & $0.5849 * * *$ \\
& $(7.10)$ & $(3.36)$ & $(4.19)$ & $(3.89)$ \\
Retailing & $0.4216^{* * *}$ & $0.4541^{* * *}$ & $0.4703 * * *$ & $0.4541^{* * *}$ \\
& $(7.19)$ & $(5.91)$ & $(4.87)$ & $(6.49)$ \\
Transportation & $0.4215^{* * *}$ & $0.4628 * * *$ & $0.4628 * * *$ & $0.5124 * * *$ \\
& $(4.20)$ & $(6.48)$ & $(5.01)$ & $(5.90)$ \\
Utility & $0.4352^{* * *}$ & $0.4907 * * *$ & $0.5185 * * *$ & $0.5370 * * *$ \\
COVID-Plus & $(4.40)$ & $(5.55)$ & $(4.59)$ & $(4.86)$ \\
Finance & & & & \\
Infrastructure & $0.4151 * * *$ & $0.4528 * * *$ & $0.4245 * * *$ & $0.4906 * * *$ \\
& $(3.56)$ & $(4.23)$ & $(5.28)$ & $(12.87)$ \\
IT & $0.5652^{* * *}$ & $0.6087 * * *$ & $0.5435 * * *$ & $0.5217 * * *$ \\
& $(3.88)$ & $(4.67)$ & $(3.64)$ & $(3.02)$ \\
Social Work & $0.5864 * * *$ & $0.5318^{* * *}$ & $0.5227 * * *$ & $0.5409 * * *$ \\
& $(9.10)$ & $(45.76)$ & $(9.57)$ & $(15.75)$ \\
& $0.4545 *$ & $0.5455^{* * *}$ & $0.6364 * * *$ & 0.4545 \\
& $(1.92)$ & $(7.01)$ & $(2.72)$ & $(1.52)$ \\
\hline
\end{tabular}

***, $* *$ and $*$ indicate the significance at $1 \%, 5 \%$ and $10 \%$ level. T-statistics are in the parentheses. EFF refers to effectiveness using event windows. 
Table 7: Factors Determining the Effects of COVID-19

\begin{tabular}{lrrrr}
\hline \multicolumn{1}{l}{ Panel A: The Baseline Specification for the Full Sample } \\
\hline Variables & CAR (-1,+1) & CAR $(-\mathbf{2},+\mathbf{2})$ & CAR $(-\mathbf{3},+3)$ & CAR (-5,+5) \\
\hline Size & $-0.0008^{* *}$ & $-0.0009^{*}$ & $-0.0009^{*}$ & -0.0003 \\
& $(-2.31)$ & $(-1.93)$ & $(-1.81)$ & $(-0.47)$ \\
ROA & 0.0087 & 0.0157 & $0.0405^{* * *}$ & $0.0590^{* * *}$ \\
& $(0.85)$ & $(1.28)$ & $(3.10)$ & $(2.92)$ \\
DOA & 0.0001 & -0.0018 & -0.0020 & -0.0063 \\
& $(0.01)$ & $(-0.40)$ & $(-0.37)$ & $(-0.91)$ \\
Fixed Assets & 0.0037 & 0.0030 & 0.0022 & -0.0010 \\
& $(1.22)$ & $(0.78)$ & $(0.50)$ & $(-0.18)$ \\
Intangible & -0.0062 & -0.0121 & $-0.0215^{* *}$ & -0.0191 \\
& $(-0.92)$ & $(-1.46)$ & $(-2.08)$ & $(-1.58)$ \\
Infection & -0.0006 & -0.0033 & $-0.0047^{*}$ & -0.0046 \\
& $(-0.33)$ & $(-1.47)$ & $(-1.76)$ & $(-1.40)$ \\
NTH & -0.0019 & 0.0004 & 0.0016 & -0.0020 \\
& $(-1.15)$ & $(0.18)$ & $(0.61)$ & $(-0.61)$ \\
BSGCT & -0.0010 & -0.0009 & -0.0017 & -0.0004 \\
& $(-0.81)$ & $(-0.60)$ & $(-0.94)$ & $(-0.17)$ \\
HB & -0.0010 & -0.0020 & -0.0052 & -0.0040 \\
& $(-0.29)$ & $(-0.41)$ & $(-0.97)$ & $(-0.56)$
\end{tabular}

Fixed Effects

Industry Controlled Controlled Controlled Controlled

Observations

5,274

5,274

5,274

5,274

Panel B: Alternative Fixed Effects

\begin{tabular}{lrrrr}
\hline Variables & CAR (-1,+1) & CAR $(-\mathbf{2},+\mathbf{2})$ & CAR $(-\mathbf{3},+\mathbf{3})$ & CAR (-5,+5) \\
\hline Size & $-0.0009^{* * *}$ & $-0.0010^{* *}$ & $-0.0011^{* *}$ & -0.0005 \\
ROA & $(-2.58)$ & $(-2.15)$ & $(-1.96)$ & $(-0.72)$ \\
& 0.0075 & 0.0143 & $0.0394^{* * *}$ & $0.0570 * * *$ \\
DOA & $(0.73)$ & $(1.17)$ & $(3.00)$ & $(2.82)$ \\
& 0.0003 & -0.0015 & -0.0017 & -0.0057 \\
Fixed Assets & $(0.10)$ & $(-0.31)$ & $(-0.31)$ & $(-0.82)$ \\
& 0.0042 & 0.0035 & 0.0027 & -0.0002 \\
Intangible & $(1.37)$ & $(0.92)$ & $(0.60)$ & $(-0.04)$ \\
& -0.0064 & -0.0123 & $-0.0218^{* *}$ & -0.0195 \\
Infection & $(-0.95)$ & $(-1.49)$ & $(-2.10)$ & $(-1.61)$ \\
& -0.0007 & -0.0034 & $-0.0048^{*}$ & -0.0047 \\
NTH & $(-0.40)$ & $(-1.53)$ & $(-1.80)$ & $(-1.46)$ \\
& -0.0019 & 0.0004 & 0.0016 & 0.0020 \\
BSGCT & $(-1.15)$ & $(0.18)$ & $(0.61)$ & $(0.61)$ \\
& -0.0008 & -0.0007 & -0.0015 & -0.0001 \\
HB & $(-0.66)$ & $(-0.47)$ & $(-0.84)$ & $(-0.03)$ \\
& -0.0010 & -0.0019 & -0.0052 & -0.0040 \\
Fixed Effects & $(-0.29)$ & $(-0.40)$ & $(-0.97)$ & $(-0.56)$ \\
Firm & & & & \\
Industry & Controlled & Controlled & Controlled & Controlled \\
Observations & Controlled & Controlled & Controlled & Controlled \\
& 5,274 & 5,274 & 5,274 & 5,274 \\
& & 52 & &
\end{tabular}




\begin{tabular}{|c|c|c|c|c|}
\hline \multicolumn{5}{|c|}{ Panel C: Alternative Event Windows } \\
\hline Variables & CAR $(0,+1)$ & CAR $(0,+2)$ & CAR $(0,+3)$ & CAR $(0,+5)$ \\
\hline \multirow[t]{2}{*}{ Size } & $-0.0008 * * *$ & $-0.0009 * * *$ & $-0.0009 * *$ & -0.0007 \\
\hline & $(-3.08)$ & $(-2.76)$ & $(-2.25)$ & $(-1.51)$ \\
\hline \multirow{2}{*}{ ROA } & 0.0085 & 0.0108 & $0.0224 * *$ & $0.0352 * * *$ \\
\hline & $(1.13)$ & $(1.28)$ & $(2.48)$ & $(2.89)$ \\
\hline \multirow[t]{2}{*}{ DOA } & 0.0019 & 0.0002 & 0.0001 & 0.0005 \\
\hline & $(0.67)$ & $(0.05)$ & $(0.02)$ & $(0.11)$ \\
\hline \multirow[t]{2}{*}{ Fixed Assets } & 0.0026 & 0.0010 & 0.0014 & 0.0004 \\
\hline & $(1.06)$ & $(0.33)$ & $(0.40)$ & $(0.09)$ \\
\hline \multirow[t]{2}{*}{ Intangible } & -0.0058 & -0.0092 & $-0.0143^{*}$ & -0.0101 \\
\hline & $(-1.01)$ & $(-1.37)$ & $(-1.73)$ & $(-1.05)$ \\
\hline \multirow[t]{2}{*}{ Infection } & -0.0002 & -0.0007 & 0.0001 & 0.0004 \\
\hline & $(-0.16)$ & $(-0.37)$ & $(0.03)$ & $(0.17)$ \\
\hline \multirow[t]{2}{*}{ NTH } & $-0.0027^{*}$ & -0.0014 & -0.0004 & 0.0002 \\
\hline & $(-1.95)$ & $(-0.85)$ & $(-0.20)$ & $(0.06)$ \\
\hline \multirow[t]{2}{*}{ BSGCT } & -0.0003 & -0.0004 & -0.0014 & -0.0005 \\
\hline & $(-0.30)$ & $(-0.32)$ & $(-0.99)$ & $(-0.29)$ \\
\hline \multirow[t]{2}{*}{$\mathrm{HB}$} & -0.0019 & -0.0030 & $-0.0078 * *$ & -0.0021 \\
\hline & $(-0.67)$ & $(-0.84)$ & $(-2.01)$ & $(-0.40)$ \\
\hline \multicolumn{5}{|l|}{ Fixed Effects } \\
\hline Industry & Controlled & Controlled & Controlled & Controlled \\
\hline Observations & 5,274 & 5,274 & 5,274 & 5,274 \\
\hline \multicolumn{5}{|c|}{ Panel D: The Effects of the Quarantine of Wuhan } \\
\hline Variables & CAR $(-1,+1)$ & CAR $(-2,+2)$ & CAR $(-3,+3)$ & CAR $(-5,+5)$ \\
\hline \multirow[t]{2}{*}{ Size } & $-0.0008 * *$ & $-0.0009^{*}$ & $-0.0009^{*}$ & -0.0003 \\
\hline & $(-2.30)$ & $(-1.92)$ & $(-1.78)$ & $(-0.45)$ \\
\hline \multirow[t]{2}{*}{ ROA } & 0.0086 & 0.0156 & $0.0405 * * *$ & $0.0590 * * *$ \\
\hline & $(0.84)$ & $(1.27)$ & $(3.10)$ & $(2.93)$ \\
\hline \multirow[t]{2}{*}{ DOA } & -0.0001 & -0.0019 & -0.0020 & -0.0063 \\
\hline & $(-0.01)$ & $(-0.41)$ & $(-0.38)$ & $(-0.91)$ \\
\hline \multirow[t]{2}{*}{ Fixed Assets } & 0.0037 & 0.0030 & 0.0022 & -0.0010 \\
\hline & $(1.22)$ & $(0.78)$ & $(0.50)$ & $(-0.18)$ \\
\hline \multirow[t]{2}{*}{ Intangible } & -0.0061 & -0.0120 & $-0.0214 * *$ & -0.0190 \\
\hline & $(-0.90)$ & $(-1.44)$ & $(-2.07)$ & $(-1.57)$ \\
\hline \multirow[t]{2}{*}{ Infection } & $-0.0088 * *$ & $-0.0148 * * *$ & $-0.0182 * * *$ & $-0.0156^{* *}$ \\
\hline & $(-2.07)$ & $(-2.67)$ & $(-2.93)$ & $(-2.13)$ \\
\hline \multirow[t]{2}{*}{ Infection*Block } & $0.0099 * *$ & $0.0139 * *$ & $0.0163 * *$ & $0.0134^{*}$ \\
\hline & (2.13) & $(2.31)$ & $(2.41)$ & (1.65) \\
\hline \multirow[t]{2}{*}{ Block } & $0.0033 * *$ & $0.0047 * *$ & 0.0024 & 0.0010 \\
\hline & (2.11) & $(2.28)$ & $(1.02)$ & $(0.31)$ \\
\hline \multirow[t]{2}{*}{ NTH } & -0.0017 & 0.0007 & 0.0018 & 0.0022 \\
\hline & $(-1.03)$ & $(0.31)$ & $(0.71)$ & $(0.67)$ \\
\hline \multirow[t]{2}{*}{ BSGCT } & -0.0012 & -0.0012 & -0.0020 & -0.0006 \\
\hline & $(-1.00)$ & $(-0.83)$ & $(-1.13)$ & $(-0.28)$ \\
\hline \multirow[t]{2}{*}{ HB } & -0.0003 & -0.0009 & -0.0043 & -0.0034 \\
\hline & $(-0.09)$ & $(-0.20)$ & $(-0.81)$ & $(-0.47)$ \\
\hline
\end{tabular}




\begin{tabular}{|c|c|c|c|c|}
\hline $\begin{array}{l}\text { Industry } \\
\text { Observations }\end{array}$ & $\begin{array}{r}\text { Controlled } \\
5,274 \\
\end{array}$ & $\begin{array}{r}\text { Controlled } \\
5,274 \\
\end{array}$ & $\begin{array}{r}\text { Controlled } \\
5,274 \\
\end{array}$ & $\begin{array}{r}\text { Controlled } \\
5,274 \\
\end{array}$ \\
\hline \multicolumn{5}{|c|}{ Panel E: The Effects of the Work-Resumption } \\
\hline Variables & $\operatorname{CAR}(-1,+1)$ & CAR $(-2,+2)$ & CAR $(-3,+3)$ & $\operatorname{CAR}(-5,+5)$ \\
\hline \multirow[t]{2}{*}{ Size } & $-0.0008 * *$ & $-0.0009^{*}$ & $-0.0009^{*}$ & -0.0003 \\
\hline & $(-2.31)$ & $(-1.92)$ & $(-1.78)$ & $(-0.44)$ \\
\hline \multirow[t]{2}{*}{ ROA } & 0.0088 & 0.0158 & $0.0408^{* * *}$ & $0.0592 * * *$ \\
\hline & $(0.86)$ & $(1.30)$ & $(3.12)$ & $(2.94)$ \\
\hline \multirow[t]{2}{*}{ DOA } & 0.0001 & -0.0017 & -0.0019 & -0.0062 \\
\hline & $(0.02)$ & $(-0.38)$ & $(-0.35)$ & $(-0.90)$ \\
\hline \multirow[t]{2}{*}{ Fixed Assets } & 0.0037 & 0.0029 & 0.0021 & -0.0011 \\
\hline & $(1.21)$ & $(0.76)$ & $(0.48)$ & $(-0.19)$ \\
\hline \multirow[t]{2}{*}{ Intangible } & -0.0062 & -0.0121 & $-0.0216^{* *}$ & -0.0192 \\
\hline & $(-0.92)$ & $(-1.47)$ & $(-2.09)$ & $(-1.59)$ \\
\hline \multirow[t]{2}{*}{ Infection } & -0.0020 & $-0.0066^{*}$ & $-0.0091 * *$ & $-0.0086^{*}$ \\
\hline & $(-0.72)$ & $(-1.90)$ & $(-2.18)$ & $(-1.76)$ \\
\hline \multirow[t]{2}{*}{ Infection *Work } & 0.0024 & 0.0058 & 0.0074 & 0.0067 \\
\hline & $(0.70)$ & $(1.33)$ & $(1.44)$ & $(1.08)$ \\
\hline \multirow[t]{2}{*}{ Work } & 0.0015 & 0.0005 & 0.0008 & -0.0004 \\
\hline & $(1.16)$ & $(0.23)$ & $(0.45)$ & $(-0.16)$ \\
\hline \multirow[t]{2}{*}{ NTH } & -0.0019 & 0.0005 & 0.0017 & 0.0020 \\
\hline & $(-1.12)$ & $(0.23)$ & $(0.64)$ & $(0.62)$ \\
\hline \multirow[t]{2}{*}{ BSGCT } & -0.0009 & -0.0007 & -0.0015 & -0.0003 \\
\hline & $(-0.71)$ & $(-0.47)$ & $(-0.88)$ & $(-0.16)$ \\
\hline \multirow[t]{2}{*}{ HB } & -0.0008 & -0.0016 & -0.0050 & -0.0039 \\
\hline & $(-0.24)$ & $(-0.33)$ & $(-0.93)$ & $(-0.54)$ \\
\hline \multicolumn{5}{|l|}{ Fixed Effects } \\
\hline Industry & Controlled & Controlled & Controlled & Controlled \\
\hline Observations & 5,274 & 5,274 & 5,274 & 5,274 \\
\hline \multicolumn{5}{|c|}{ Panel F: The Baseline Specification for the Exponential Growth Sample } \\
\hline Variables & $\operatorname{CAR}(-1,+1)$ & CAR $(-2,+2)$ & CAR $(-3,+3)$ & CAR $(-5,+5)$ \\
\hline \multirow[t]{2}{*}{ Size } & -0.0001 & 0.0001 & -0.0003 & 0.0005 \\
\hline & $(-0.19)$ & $(0.10)$ & $(-0.31)$ & $(0.43)$ \\
\hline \multirow[t]{2}{*}{ ROA } & -0.0029 & -0.0121 & 0.0198 & 0.0203 \\
\hline & $(-0.15)$ & $(-0.53)$ & $(0.85)$ & $(0.54)$ \\
\hline \multirow[t]{2}{*}{ DOA } & -0.0029 & -0.0120 & -0.0123 & $-0.0235^{*}$ \\
\hline & $(-0.51)$ & $(-1.44)$ & $(-1.30)$ & $(-1.75)$ \\
\hline \multirow[t]{2}{*}{ Fixed Assets } & 0.0039 & 0.0050 & 0.0047 & -0.0018 \\
\hline & $(0.79)$ & $(0.76)$ & $(0.61)$ & $(-0.18)$ \\
\hline \multirow[t]{2}{*}{ Intangible } & -0.0158 & -0.0167 & $-0.0271 *$ & -0.0176 \\
\hline & $(-1.52)$ & $(-1.29)$ & $(-1.70)$ & $(-0.86)$ \\
\hline \multirow[t]{2}{*}{ Infection } & -0.0029 & $-0.0078 * *$ & $-0.0112 * *$ & $-0.0090^{*}$ \\
\hline & $(-1.02)$ & $(-2.11)$ & $(-2.52)$ & $(-1.76)$ \\
\hline \multirow[t]{2}{*}{ NTH } & 0.0014 & 0.0032 & 0.0044 & 0.0051 \\
\hline & $(0.46)$ & $(0.80)$ & $(0.92)$ & $(0.84)$ \\
\hline BSGCT & 0.0010 & 0.0007 & 0.0008 & 0.0017 \\
\hline & $(0.50)$ & $(0.27)$ & $(0.25)$ & $(0.45)$ \\
\hline $\mathrm{HB}$ & 0.0016 & -0.0043 & -0.0030 & -0.0054 \\
\hline
\end{tabular}




\begin{tabular}{|c|c|c|c|c|}
\hline & $(0.24)$ & $(-0.55)$ & $(-0.35)$ & $(-0.45)$ \\
\hline \multicolumn{5}{|l|}{ Fixed Effects } \\
\hline Industry & Controlled & Controlled & Controlled & Controlled \\
\hline Observations & 1,765 & 1,765 & 1,765 & 1,765 \\
\hline \multicolumn{5}{|c|}{ Panel G: The Baseline Specification for the Flattening the Curve Sample } \\
\hline Variables & CAR $(-1,+1)$ & CAR $(-2,+2)$ & CAR $(-3,+3)$ & $\operatorname{CAR}(-5,+5)$ \\
\hline \multirow[t]{2}{*}{ Size } & $-0.0011 * * *$ & $-0.0013 * *$ & $-0.0013^{* *}$ & -0.0007 \\
\hline & $(-2.62)$ & $(-2.47)$ & $(-1.98)$ & $(-0.97)$ \\
\hline \multirow[t]{2}{*}{ ROA } & 0.0150 & $0.0321 * *$ & $0.0525^{* * *}$ & $0.0820 * * *$ \\
\hline & $(1.35)$ & $(2.40)$ & $(3.42)$ & $(3.71)$ \\
\hline \multirow[t]{2}{*}{ DOA } & 0.0015 & 0.0039 & 0.0036 & 0.0032 \\
\hline & $(0.37)$ & $(0.72)$ & $(0.56)$ & $(0.41)$ \\
\hline \multirow[t]{2}{*}{ Fixed Assets } & 0.0038 & 0.0020 & 0.0010 & -0.0007 \\
\hline & $(0.96)$ & $(0.41)$ & $(0.18)$ & $(-0.10)$ \\
\hline \multirow[t]{2}{*}{ Intangible } & -0.0012 & -0.0101 & -0.0185 & -0.0207 \\
\hline & $(-0.13)$ & $(-0.93)$ & $(-1.37)$ & $(-1.36)$ \\
\hline \multirow[t]{2}{*}{ Infection } & 0.0009 & -0.0002 & -0.0006 & -0.0015 \\
\hline & $(0.37)$ & $(-0.07)$ & $(-0.17)$ & $(-0.35)$ \\
\hline \multirow[t]{2}{*}{$\mathrm{NTH}$} & $-0.0034^{*}$ & -0.0008 & 0.0003 & 0.0004 \\
\hline & $(-1.67)$ & $(-0.29)$ & $(0.10)$ & $(0.11)$ \\
\hline \multirow[t]{2}{*}{ BSGCT } & -0.0017 & -0.0012 & -0.0024 & -0.0010 \\
\hline & $(-1.17)$ & $(-0.66)$ & $(-1.11)$ & $(-0.38)$ \\
\hline \multirow[t]{2}{*}{$\mathrm{HB}$} & -0.0021 & 0.0008 & -0.0056 & -0.0019 \\
\hline & $(-0.53)$ & $(0.13)$ & $(-0.82)$ & $(-0.21)$ \\
\hline \multicolumn{5}{|l|}{ Fixed Effects } \\
\hline Industry & Controlled & Controlled & Controlled & Controlled \\
\hline Observations & 3,509 & 3,509 & 3,509 & 3,509 \\
\hline
\end{tabular}


Table 8: The Factors Determining the Sector-Level Effectiveness

\begin{tabular}{lrrrr}
\hline \multicolumn{4}{l}{ Panel A: Factors Determining Effectiveness in the Exponential Growth Sample } \\
\hline \multicolumn{1}{l}{ Variables } & EFF (-1,+1) & EFF (-2,+2) & EFF (-3,+3) & EFF (-5,+5) \\
\hline Size & $-0.0022^{*}$ & $-0.0019^{*}$ & $-0.0023^{* *}$ & -0.0010 \\
& $(-1.95)$ & $(-1.79)$ & $(-2.20)$ & $(-0.94)$ \\
ROA & 0.0188 & 0.0051 & 0.0110 & 0.0002 \\
& $(0.94)$ & $(0.27)$ & $(0.61)$ & $(0.01)$ \\
DOA & 0.0038 & 0.0056 & $0.0176^{* *}$ & 0.0134 \\
& $(0.38)$ & $(0.59)$ & $(2.00)$ & $(1.47)$ \\
Fixed Assets & $-0.0268^{* *}$ & $-0.0200^{* *}$ & -0.0083 & -0.0061 \\
& $(-2.56)$ & $(-1.98)$ & $(-0.91)$ & $(-0.60)$ \\
Intangible & -0.0016 & -0.0040 & -0.0 .0198 & -0.0135 \\
& $(-0.06)$ & $(-0.18)$ & $(-0.87)$ & $(-0.71)$ \\
Infection & $-0.1107 * * *$ & $-0.1167 * * *$ & $-0.0814^{* * *}$ & $-0.1264 * *$ \\
& $(-12.26)$ & $(-15.04)$ & $(-11.25)$ & $(-16.81)$ \\
NTH & -0.0018 & -0.0040 & -0.0088 & $-0.0144 * *$ \\
& $(-0.29)$ & $(-0.68)$ & $(-1.56)$ & $(-2.50)$ \\
BSGCT & $0.0086^{* *}$ & $0.0119^{* * *}$ & $0.0152^{* * *}$ & $0.0182^{* * *}$ \\
& $(2.25)$ & $(3.18)$ & $(3.94)$ & $(4.37)$ \\
HB & 0.0094 & 0.0107 & 0.0005 & 0.0066 \\
& $(0.88)$ & $(1.10)$ & $(0.05)$ & $(0.60)$
\end{tabular}

Fixed Effects

Industry

Controlled

Controlled

Controlled

Controlled

1,765

1,765

1,765

1,765

R-square

0.2262

0.2694

0.1873

0.2490

Panel B: Factors Determining Effectiveness in the Flattening the Curve Sample

\begin{tabular}{|c|c|c|c|c|}
\hline Variables & EFF $(-1,+1)$ & EFF $(-2,+2)$ & EFF $(-3,+3)$ & $\operatorname{EFF}(-5,+5)$ \\
\hline \multirow[t]{2}{*}{ Size } & $-0.0016^{*}$ & $-0.0021 * * *$ & -0.0015 & -0.0005 \\
\hline & $(-1.95)$ & $(-2.71)$ & $(-1.54)$ & $(-0.59)$ \\
\hline \multirow[t]{2}{*}{ ROA } & 0.0035 & -0.0002 & 0.0040 & $0.0275^{*}$ \\
\hline & $(0.23)$ & $(-0.01)$ & $(0.26)$ & $(1.88)$ \\
\hline \multirow[t]{2}{*}{ DOA } & -0.0049 & 0.0007 & -0.0024 & 0.0035 \\
\hline & $(-0.68)$ & $(0.11)$ & $(-0.35)$ & $(0.56)$ \\
\hline \multirow[t]{2}{*}{ Fixed Assets } & -0.0060 & -0.0106 & -0.0111 & -0.0072 \\
\hline & $(-0.83)$ & $(-1.60)$ & $(-1.55)$ & $(-1.14)$ \\
\hline \multirow[t]{2}{*}{ Intangible } & 0.0181 & 0.0005 & -0.0076 & -0.0183 \\
\hline & $(1.00)$ & $(0.03)$ & $(-0.45)$ & $(-1.27)$ \\
\hline \multirow[t]{2}{*}{ Infection } & $0.0837 * * *$ & $0.0517 * * *$ & $0.0503 * * *$ & $0.0642 * * *$ \\
\hline & (12.07)- & (10.58) & $(8.53)$ & (11.18) \\
\hline \multirow[t]{2}{*}{ NTH } & -0.0034 & -0.0028 & $-0.0071 * *$ & -0.0015 \\
\hline & $(-0.85)$ & $(-0.80)$ & $(-2.07)$ & $(-0.56)$ \\
\hline \multirow[t]{2}{*}{ BSGCT } & $0.0070 * *$ & 0.0037 & 0.0013 & -0.0012 \\
\hline & $(2.50)$ & (1.44) & $(0.46)$ & $(-0.46)$ \\
\hline \multirow[t]{2}{*}{$\mathrm{HB}$} & 0.0021 & 0.0034 & 0.0084 & -0.0044 \\
\hline & $(0.24)$ & $(0.45)$ & $(1.05)$ & $(-0.59)$ \\
\hline \multicolumn{5}{|l|}{ Fixed Effects } \\
\hline Industry & Controlled & Controlled & Controlled & Controlled \\
\hline \multirow[t]{2}{*}{ Observations } & 3,509 & 3,509 & 3,509 & 3,509 \\
\hline & & 56 & & \\
\hline
\end{tabular}


***,** and $*$ indicate the significance at $1 \%, 5 \%$ and $10 \%$ level. T-statistics are in the parentheses.

Table 9: Summary of how information management is related to SDGs

\begin{tabular}{|c|c|c|}
\hline No. & SDGs & Information management \\
\hline 1 & No poverty & $\begin{array}{l}\text { Special accommodation provided in the period of } \\
\text { quarantine and info is online }\end{array}$ \\
\hline 2 & Zero hunger & Online Grocery Shopping \\
\hline 3 & Good health and well-being & $\begin{array}{l}\text { Number of patients being diagnosed, cured and dead. } \\
\text { Medical App is used for real time tracking. Online hospital } \\
\text { and online pharmacy. }\end{array}$ \\
\hline 4 & Quality education & Usage of Online Education Technology \\
\hline 5 & Gender equality & -- \\
\hline 6 & Clean water and sanitation & $\begin{array}{l}\text { pollution decreases in the period, related organization has } \\
\text { still worked as usual, there is online customer services }\end{array}$ \\
\hline 7 & $\begin{array}{l}\text { Affordable and clean } \\
\text { energy }\end{array}$ & $\begin{array}{l}\text { related organization has still worked as usual, there is } \\
\text { online customer services }\end{array}$ \\
\hline 8 & $\begin{array}{l}\text { Decent work and economic } \\
\text { growth }\end{array}$ & Usage of Online Office App \\
\hline 9 & $\begin{array}{l}\text { Industry, innovation and } \\
\text { infrastructure }\end{array}$ & Usage of Online Office App \\
\hline 10 & Reduced inequalities & \\
\hline 11 & $\begin{array}{l}\text { Sustainable cities and } \\
\text { communities }\end{array}$ & Air Quality Index for all the cities \\
\hline 12 & $\begin{array}{l}\text { Responsible consumption } \\
\text { and production }\end{array}$ & Usage of Online Office App \\
\hline 13 & Climate action & Usage of Online Office App \\
\hline 14 & Life below water & \\
\hline 15 & Life on land & Usage of Online Office App \\
\hline 16 & $\begin{array}{l}\text { Peace, justice and strong } \\
\text { institutions }\end{array}$ & Usage of Online Office App \\
\hline 17 & Partnerships for the goals & -- \\
\hline
\end{tabular}


Appendix I: The Announcements of the Events on COVID-19

Panel A: Announcements of the Chinese Measures on COVID-19

\begin{tabular}{|c|c|c|c|c|}
\hline Date & Event & Type & Stringency & Description \\
\hline $2020 / 01 / 22$ & 1 & Prevention and Control & Stringent & The Program of the Prevention and Control of 2019-nCoV (2nd edition) \\
\hline $2020 / 02 / 5$ & 2 & Diagnosis & Stringent & $\begin{array}{l}\text { The Notice Concerning the Issuance of a Treatment Scheme for 2019-nCoV } \\
\text { The Notice of Firms to Return to Work and Produce with Proper Epidemic }\end{array}$ \\
\hline $2020 / 02 / 22$ & 3 & Back to Work & Lax & $\begin{array}{l}\text { Prevention and Control } \\
\text { The Circular on Strengthening the Guidance on Epidemic Prevention and }\end{array}$ \\
\hline $2020 / 03 / 7$ & 4 & Back to Work & Lax & $\begin{array}{l}\text { Control during the Firms' Resumption of Work and Production } \\
\text { The Notice on the Issuance of COVID-19 Health Management Protocol for }\end{array}$ \\
\hline $2020 / 03 / 13$ & 5 & Diagnosis & Stringent & $\begin{array}{l}\text { Discharged Patients (trial) } \\
\text { The Notice on the Issuance of COVID-19 Psychological Counseling Work }\end{array}$ \\
\hline $2020 / 03 / 18$ & 6 & Diagnosis & Stringent & Program \\
\hline \multicolumn{5}{|c|}{ Panel B: Milestones of Chinese Epidemic Prevention Campaign } \\
\hline Date & Milestone & Type & & Description \\
\hline $2020 / 01 / 23$ & 1 & Prevention and Control & $\begin{array}{l}\text { Wuhan was } \\
\text { which marks } \\
\text { Chinese resi } \\
\text { President Xi } \\
\text { visiting a ho } \\
\text { confidence. }\end{array}$ & $\begin{array}{l}\text { laced under effective quarantine as air and rail departures were suspended, } \\
\text { the turning point of Chinese epidemic prevention campaign. } \\
\text { ents started to return to work after the Spring Festival holidays. } \\
\text { Jinping appeared to the public for the first time since the epidemic began, } \\
\text { pital in Beijing and urging Chinese to fight the battle against the virus with }\end{array}$ \\
\hline
\end{tabular}




\section{Appendix II: Matrix of COVID-Minus and COVID-Plus for Various Sectors}

\section{Sectors \\ Expectation and Explanation}

COVID-Minus

Agriculture

Is expected to be negatively affected by home quarantine due to decreasing work force and is expected to be positively affected after home quarantine.

Construction Is expected to be negatively affected by home quarantine due to decreasing work force and is expected to be positively affected after home quarantine.

Culture Is expected to be negatively affected by home quarantine due to decreasing participants and is expected to be positively affected after home quarantine.

Is expected to be negatively affected by home quarantine due to decreasing teachers and students as well as the decreasing level and quality of online education and is expected to be positively affected after home quarantine. In

Education addition, the period of 2020/01/24 to 2020/02/02 is the Chinese Spring Festival holiday period and the period January to March of 2020 is the winter holidays for all Chinese students. A limited number of teachers and students from few cities/provinces returned to school after April due to the virus.

Is expected to be negatively affected due to decreasing work force and

Hotel increasing closed hotels and is expected to be positively affected after home quarantine. Travelers also faced travel bans and restrictions such as 14 days quarantine.

Is expected to be negatively affected by home quarantine due to decreasing

Leasing work force and customers and the lower efficiency from working from home and is expected to be positively affected after home quarantine. Firms stopped their leasing contracts to protect their properties and equipment.

Minerals Is expected to be negatively affected by home quarantine due to decreasing work force and is expected to be positively affected after home quarantine.

Manufacturing Is expected to be negatively affected by home quarantine due to decreasing work force and is expected to be positively affected after home quarantine.

Is expected to be negatively affected by home quarantine and lack of

Real Estate financing. Tenants also stopped leasing contracts before the Spring Festival and landlords stopped letting properties to tenants after the Wuhan quarantine to protect their properties.

Is expected to be negatively affected by home quarantine as researchers cannot access research resources from their work place and is expected to be positively affected after home quarantine. 
\begin{tabular}{ll}
\hline Is expected to be negatively affected by home quarantine due to decreasing \\
Retailing & work force and customers and is expected to be positively affected after home
\end{tabular} quarantine.

Is expected to be negatively affected by home quarantine due to decreasing

Synthesis work force and customers and is expected to be positively affected after home quarantine.

Transportation Is expected to be negatively affected by home quarantine due to decreasing work force and is expected to be positively affected after home quarantine.

Is expected to be negatively affected due to decreasing work force and

Utility consumption of businesses and organizations, despite the increasing from individuals and families due to home quarantine. The sector is expected to be positively affected after home quarantine.

\section{COVID-Plus}

Finance

Is expected to be positively affected due the inability of customers to pay back which in turn results in higher interest accrual for banks. The financial sector is expected to be negatively affected after quarantine.

Infrastructure Is expected to be positively affected as diverse infrastructure are created for the Chinese Epidemic Prevention Campaign in a short time period.

Is expected to be positively affected by home quarantine as the number of network users and relevant demands soar. These users require internet

IT resources to work and study from home, conduct online shopping, relax and engage in social distancing. The IT sector is expected to be positively affected after home quarantine.

Is expected to be positively affected. Diverse types of services have been provided for the Chinese Epidemic Prevention Campaign. The service sector is expected to be positively affected after home quarantine.

Is expected to be positively affected. Social work services are created and

Social Work provided for the Chinese Epidemic Prevention Campaign. The social work sector is expected to be positively affected after home quarantine. 


\begin{tabular}{|c|c|}
\hline Variables & Definitions \\
\hline \multicolumn{2}{|c|}{ Abnormal Returns } \\
\hline $\operatorname{CAR}(-1,+1)$ & Cumulative abnormal returns across event window $(-1,+1)$. \\
\hline $\operatorname{CAR}(-2,+2)$ & Cumulative abnormal returns across event window $(-2,+2)$. \\
\hline $\operatorname{CAR}(-3,+3)$ & Cumulative abnormal returns across event window $(-3,+3)$. \\
\hline $\operatorname{CAR}(-5,+5)$ & Cumulative abnormal returns across event window $(-5,+5)$. \\
\hline \multicolumn{2}{|l|}{ Effectiveness } \\
\hline$\overline{\operatorname{EFF}(-1,+1)}$ & Sector-level effectiveness scores computed using CAR $(-1,+1)$. \\
\hline $\operatorname{EFF}(-2,+2)$ & Sector-level effectiveness scores computed using CAR $(-2,+2)$. \\
\hline $\operatorname{EFF}(-3,+3)$ & Sector-level effectiveness scores computed using CAR $(-3,+3)$. \\
\hline $\mathrm{EFF}(-5,+5)$ & Sector-level effectiveness scores computed using CAR $(-5,+5)$. \\
\hline \multicolumn{2}{|c|}{ Financial Fundamentals } \\
\hline$\overline{\text { Size }}$ & The measure of firm size, the natural logarithm of total assets. \\
\hline ROA & The measure of firm profitability, the ratio of net return on assets. \\
\hline DOA & The measure of firm liability, total liability divided by total assets. \\
\hline Fixed Assets & The ratio of firm fixed assets to total assets. \\
\hline Intangible & The ratio of firm intangible assets to total assets. \\
\hline \multicolumn{2}{|c|}{ COVID-19 Related Variables } \\
\hline Infection & $\begin{array}{l}\text { Dummy variable, a measure to define the feature of a firm, which } \\
\text { takes the value of } 1 \text { if the firm is positively affected during home } \\
\text { quarantine and is negatively affected after quarantine, and } 0 \\
\text { otherwise. COVID-Minus is the firm with reverse scenario-is } \\
\text { negatively affected during home quarantine and is positively } \\
\text { affected after quarantine. Details are listed in Appendix II. }\end{array}$ \\
\hline $\mathrm{NTH}$ & $\begin{array}{l}\text { Dummy variable, which takes the value of } 1 \text { if the city or province } \\
\text { where a firm locates is next to Hubei, and } 0 \text { otherwise. }\end{array}$ \\
\hline BSGCT & $\begin{array}{l}\text { Dummy variable, which equals } 1 \text { if the city or province where a } \\
\text { firm locates is one of Beijing, Shanghai, Guangdong, Chongqing } \\
\text { and Tianjin, which are municipalities directly under the central } \\
\text { government and first-tier cities with higher local GDP and level } \\
\text { of medical standards in China, and } 0 \text { otherwise. }\end{array}$ \\
\hline
\end{tabular}




\begin{tabular}{|c|c|}
\hline $\mathrm{HB}$ & $\begin{array}{l}\text { Dummy variable, which takes the value of } 1 \text { if the city or province } \\
\text { where the firm locates is within Hubei, and } 0 \text { otherwise. }\end{array}$ \\
\hline Block & $\begin{array}{l}\text { Dummy variable, which equals } 1 \text { if the observation occurs after } \\
\text { the quarantine of Wuhan on } 23 \text { th of Jan, } 2020 \text {, and } 0 \text { otherwise. }\end{array}$ \\
\hline Work & $\begin{array}{l}\text { Dummy variable, which equals } 1 \text { if the observation occurs after } \\
\text { the return-to-work time, and } 0 \text { otherwise. }\end{array}$ \\
\hline \multicolumn{2}{|c|}{ Alternative Event Windows } \\
\hline$\overline{\operatorname{CAR}}(0,+1)$ & Cumulative abnormal returns across event window $(0,+1)$. \\
\hline $\operatorname{CAR}(0,+2)$ & Cumulative abnormal returns across event window $(0,+2)$. \\
\hline $\operatorname{CAR}(0,+3)$ & Cumulative abnormal returns across event window $(0,+3)$. \\
\hline $\operatorname{CAR}(0,+5)$ & Cumulative abnormal returns across event window $(0,+5)$. \\
\hline \multicolumn{2}{|l|}{ Fixed Effects } \\
\hline$\overline{\text { Firm }}$ & Firm dummy variables. \\
\hline Industry & Industry dummy variables, which stand for the industries. \\
\hline
\end{tabular}

